\title{
Early Paleozoic tectonic reconstruction of Iran: Tales from detrital zircon geochronology
}

Hadi Shafaii Moghadam a,b, ${ }^{*}$, Xian-Hua Li c, William L. Griffin b, Robert J. Stern ${ }^{d}$, Tonny B. Thomsen e, Guido Meinhold f, Reza Aharipour a, Suzanne Y. O'Reilly ${ }^{b}$

a School of Earth Sciences, Damghan University, Damghan 36716-41167, Iran

b ARC Centre of Excellence for Core to Crust Fluid Systems and GEMOC ARC National Key Centre, Department of Earth and Planetary Sciences, Faculty of Science and Engineering, Macquarie University, NSW 2109, Australia

c State Key Laboratory of Lithospheric Evolution, Institute of Geology and Geophysics, Chinese Academy of Sciences, Beijing 100029, China

d Geosciences Dept., University of Texas at Dallas, Richardson, TX 75083-0688, USA

e Geological Survey of Denmark and Greenland, Øster Voldgade 10, DK-1350 Copenhagen K, Denmark

f Geowissenschaftliches Zentrum der Universität Göttingen, Abteilung Sedimentologie und Umweltgeologie, Goldschmidtstraße 3, D-37077 Göttingen, Germany

* Corresponding author at: ARC Centre of Excellence for Core to Crust Fluid Systems and GEMOC ARC National Key Centre, Department of Earth and Planetary Sciences, Faculty of Science and Engineering, Macquarie University, NSW2109, Australia.

E-mail address: hadishafaii@yahoo.com (H.S. Moghadam). 


\section{Abstract}

In this study we use detrital zircons to probe the Early Paleozoic history of NE Iran and evaluate the link between sediment sources and Gondwanan pre-Cadomian, Cadomian and younger events. $\mathrm{U}-\mathrm{Pb}$ zircon ages and $\mathrm{Hf}$ isotopic compositions are reported for detrital zircons from Ordovician and Early Devonian sedimentary rocks from NE Iran. These clastic rocks are dominated by zircons with major age populations at $\sim 2.5 \mathrm{Ga}$, $\sim 0.8-0.6 \mathrm{Ga}, 0.5 \mathrm{Ga}$ and $\sim 0.5-0.4 \mathrm{Ga}$ as well as a minor broad peak at $\sim 1.0 \mathrm{Ga}$. The source of $2.5 \mathrm{Ga}$ detrital zircons is enigmatic; they may have been supplied from the Saharan Metacraton (or West African Craton) to the southwest or Afghanistan-Tarim to the east. The detrital zircons with age populations at 0.8-0.6 Ga probably originated from Cryogenian-Ediacaran juvenile igneous rocks of the Arabian-Nubian Shield; this inference is supported by their juvenile Hf isotopes, although some negative $\varepsilon H f(t)$ values suggest that other sources (such as the West African Craton) were also involved. The age peak at ca 0.5 Ga correlates with Cadomian magmatism reported from Iranian basement and elsewhere in north Gondwana. The variable $\varepsilon H f(t)$ values of Cadomian detrital zircons, resembling the $\varepsilon \mathrm{Hf}(\mathrm{t})$ values of zircons in magmatic Cadomian rocks from Iran and Taurides (Turkey), suggest an Andean-type margin and the involvement of reworked older crust in the generation of the magmatic rocks. The youngest age population at $0.5-0.4 \mathrm{Ga}$ is interpreted to represent Gondwana rifting and the opening of Paleotethys, which probably started in Late Cambrian-Ordovician time. A combination of $\mathrm{U}-\mathrm{Pb}$ dating and Hf-isotope data from Iran, Turkey and North Gondwana confirms that Iran and Turkey were parts of Gondwana at least until late Paleozoic time.

Keywords: Detrital zircon; Hf isotopes; Cadomian magmatism; Paleotethys; NE Iran

\section{Introduction}

The formation of Iran's continental crust largely reflects a Late Neoproterozoic-Early Cambrian-"Cadomian"-continental arc that formed on the margin of northern Gondwana and then rifted away and was transferred to southern Eurasia, although the timing of these events is controversial (Abbo et al., 2015; Berberian and King, 1981; 
Garfunkel, 2004; Robertson et al., 1991). Paleozoic clastic sediments deposited on this crust should reflect the change of source regions, first from Gondwana, then from the Iranian micro-continent, as this transition progressed. The study of Paleozoic clastic sediments in Iran thus provides a way to investigate these linkages as well as to identify sources within Iran itself. Although this approach is promising, there are as yet few such studies on Paleozoic clastic sediments of Iran. There has been one study of detrital zircon U-Pb ages fromthe Paleozoic sediments of Iran (Horton et al., 2008), using two samples from the Alborz region in the north and two samples from the south (Fig. 1). From the Alborz region, sandstones from the Late Devonian-Early Carboniferous Geirud Formation and Lower Permian Dorud Formation were analyzed. These yielded probability peaks at 370 and $325 \mathrm{Ma}$, and mean $\mathrm{U}-\mathrm{Pb}$ ages for the five youngest zircons at $348 \pm 19 \mathrm{Ma}$ and $294 \pm 18 \mathrm{Ma}$, respectively (Horton et al., 2008). These young detrital zircon populations provide insights into local magmatism related to Paleotethys rifting, and magmatism within the northern Gondwana (present Kopet Dagh region) (Moghadam and Stern, 2014; Moghadam et al., 2015b). Detrital zircons from the Devonian Zakeen Formation and Lower Permian Faraghan Formation sandstones of Zagros yielded age populations at 2.5, 0.9-0.8, 0.7 and 0.6-0.5Ga (Horton et al., 2008), dominated by sources like the Arabian-Nubian Shield, to which Iran may have been attached throughout much of Early Paleozoic time.

In this study, we present new $\mathrm{U}-\mathrm{Pb}$ ages and Hf-isotope compositions of detrital zircons from Ordovician and Devonian sandstones collected at two sites in NE Iran, and use this information along with the results of Horton et al. (2008) to better constrain the evolution of Iranian sediment source regions during Early and Middle Paleozoic time. We focus on Ordovician and middle Devonian clastic successions (Qelli - or Ghelli - and Padeha Formations) in NE Iran. We also report the age of magmatic zircons from A-type granitic boulders within conglomerates at the base of Member 1 Padeha Formation. The recent identification of distinct populations of detrital zircons from different parts of North Africa and the Arabian-Nubian Shield by (Meinhold et al., 2013) allows us to compare the Ordovician-Devonian sandstones and constrain the original location of Iran in northern Gondwana. 


\section{Geological background}

Late Neoproterozoic-Early Cambrian sedimentary successions outcrop across Iran (Fig. 1). These consist of siliciclastic and carbonate dominated sequences including the Soltanieh, Barut, Zagun, Lalun, Rizu and Dezu Formations that rest on Cadomian basement (Berberian and King, 1981) (Fig. 2). Some of the oldest formations - such as Kahar, Tashk and Morad - are intruded by 560-540 Ma granitoids and therefore were deposited before or during Cadomian magmatism. The Kahar Formation in northern Iran includes thick diamictites with ca 560-550 Ma ages for the youngest detrital zircons (Etemad-Saeed et al., 2015; Hassanzadeh et al., 2008), consistent with an Ediacaran depositional age. The Tashk Formation is also considered to be Ediacaran based on regional lithostratigraphic correlations (Hamdi, 1995; Ramezani and Tucker, 2003). The oldest detrital zircons from the Tashk Formation have U-Pb ages of ca 1.8 Ga (Ramezani and Tucker, 2003). These Neoproterozoic sedimentary successions in Iran are broadly equivalent to siliciclastics in the Menderes massif of Western Turkey (Kröner and Şengör, 1990) and also are similar to the Karacahisar basement metasediments in the Taurides (Abbo et al., 2015).

The Cadomian sedimentary succession of Iran is conformably overlain by thick Early to Middle Paleozoic strata consisting of carbonate and clastic sediments (Horton et al., 2008; Stocklin, 1968). Incomplete Silurian and Carboniferous sedimentary successions scattered across Iran suggest periods of non-deposition and erosion (Ghavidel-syooki, 2006; Wendt et al., 2005), the significance of which is not yet fully understood. Despite lithological and lithostratigraphic similarities, Paleozoic strata in northern Iran (Alborz and Kopet Dagh), central Iran, and Zagros have different names (Fig. 2).

Ediacaran to Late Paleozoic sedimentary sequences ( $>4 \mathrm{~km}$ thick) are exposed over N600 km along the Alborz, from Zanjan in the west to Shahrud in the east (Fig. 1). Further east, the eastern Alborz sedimentary successions change into their equivalents in the Kopet Dagh zone, with the same ages butwith different depositional environments (Berberian and King, 1981). Our studies have focused on sections in easternmost Alborz (Khosh Yeylagh) and Kopet-Dagh (north of Jajarm). Early to Middle Palaeozoic strata are well-exposed around Shirooyeh village, north of Jajarm and along the road from Shahrud to Gorgan, in the Khosh Yeylagh valley (Figs. 1, 3, 4). North of Shirooyeh village, Paleozoic sedimentary successions exposed on the northern limb of a faulted anticline 
consist of the Barut, Lalun, Mila, Lashkarak, Qelli, Padeha and Khosh Yeylagh Formations (Ghavidel-syooki and Vecoli, 2007) (Fig. 3). In this area, the Mila Formation conformably overlies Early Cambrian sandstones of the Barut Formation. Palynological studies (Ghavidelsyooki and Winchester-Seeto, 2002) show that the Mila Formation has a Middle-Late Cambrian age. The Early Ordovician Lashkarak Formation (250 m thick) in this area consists mainly of olive-gray shales with interbedded thin, brecciated limestone layers (Ghavidel-syooki and Vecoli, 2007). The Middle to Late Ordovician Qelli Formation is $\sim 1000 \mathrm{~m}$ thick and is characterized by dark to olive-gray shales associated with subordinate siltstone and fine-grained sandstone beds (Ghavidel-syooki and Winchester-Seeto, 2002). In our sampling area, the Qelli Formation is tectonically juxtaposed close to the Mila Formation with a fault contact and is characterized by abundant andesitic to basaltic rocks and arkosic sandstones (Fig. 5). Andesitic and basaltic lavas (with massive and pillowed structure) are abundant in this area. These volcanic rocks are thought to be slightly older equivalents of Late Ordovician-Silurian Soltan-Meidan Formation (Aharipour et al., 2010). The Niur Formation in our study area is a thin and discontinuous layer, consisting of thin layers of shale and sandstone interbedded with fossiliferous limestone. The Lower to Middle Devonian Padeha Formation is overlain by the Middle to Late Devonian Khosh Yeylagh limestones and red sandstones. Recent palynological studies indicate Late Devonian ages for both Padeha and Khosh Yeylagh Formations (Ghavidel-syooki and Vecoli, 2007).

Farther west in NE Iran, Paleozoic sedimentary rocks along the Shahrud-Gorgan road include the Qelli, Soltan-Meidan basalts, Padeha and Khosh Yeylagh Formations (Fig. 4). In this region, the mafic to intermediate volcanic rocks of the Late OrdovicianSilurian Soltan Maidan Formation are suggested to overlie the Qelli Formation along with conglomerates and siliciclastic rocks $(\sim 10 \mathrm{~m})$ at its base (Ghavidel-Syooki et al., 2011; Stampfli, 1978). The Padeha Formation north of Shahrud is $~ 300 \mathrm{~m}$ thick and non-conformably underlain by the Soltan Meidan basaltic rocks.

The Padeha Formation north of Shahrud can be subdivided into three members (Aharipour et al., 2010) (Fig. 5), a sequence that reveals Devonian uplift and erosion followed by marine transgression. From bottom to top:

(a) Member 1 has a variable thickness up to $10 \mathrm{~m}$ and mainly consists of red conglomerates, containing abundant pebble to boulder-sized $(3-50 \mathrm{~cm})$ igneous or sedimentary clasts (Fig. 6A). Red siltstones, green tuffs and interlayers of basaltic to 
andesitic massive and pillowed lavas are also common between the conglomerate layers. Locally-derived boulders of A-type granite are an important clast type (Fig. 6B), for which zircon $\mathrm{U}-\mathrm{Pb}$ dating shows a concordia age of $441.0 \pm 3.1 \mathrm{Ma}$ (see next section).

(b) Member 2 starts with whitish quartz-arenites that rest on basaltic lavas (of member 1) with a clear unconformity. Alternating quartz-arenites, arkosic sandstones, and greywackes with red shales are common in this member (Fig. 6C).

(c) Member 3 is characterized by carbonate layers along with fine-grained siliciclastic rocks and red to green shales (Fig. 6D). The carbonates consist of abundant yellowish calcretes and dolocretes. Red siliciclastic rocks and limestones of the Khosh Yeylagh Formation disconformably overlie the Padeha Formation.

\section{Field observations and sample description}

Seven samples from the Lower to Middle Paleozoic sedimentary successions both from Shirooyeh village (four samples) and from along the Shahrud-Gorgan road (three samples) were studied. The location of samples is shown in the geological map (Figs. 3 \& 4) and on a lithological section (Fig. 5).

\subsection{Shirooyeh village}

From the eastern study area (Fig. 3), we collected four samples from north of Shirooyeh village, along a valley through the sedimentary successions.

\subsubsection{Sample G11-1}

This is an arkosic sandstone from the lower parts of the Qelli Formation which is stratigraphically between the mafic-intermediate lava flows. This sample includes abundant angular, fine to medium sized quartz and K-feldspar grains. Quartz grains have magmatic (monocrystalline) and sedimentary (polycrystalline cherts) origins. Accessory minerals include zircon, rutile, and hematite along with volcanic fragments. 
This is an arkosic sandstone rich in bitumen from the Ordovician Qelli Formation which is stratigraphically above basaltic-andesitic lava flows (Fig. 5). This sample contains abundant angular to sub-rounded, fine to medium-sized K-feldspar and quartz grains. Quartz grains have magmatic and sedimentary origins. Accessory minerals include zircon, microcline and mica along with volcanic fragments and bitumen material.

\subsubsection{Sample GP-9}

This whitish quartz arenite sample was taken from the stratigraphically lowermost part of the Devonian Padeha Formation. It is coarse-grained and the quartz grains commonly show pressure solution and undulose extinction in thin section. Microcline and rare detrital albite are largely replaced by sericite. Titanite, zircon, detrital micas, iron oxides and lithic fragments are also present.

\subsubsection{Sample GP-12}

A sample of feldspathic wacke was collected from the uppermost Padeha Formation. This sample mainly consists of angular to subrounded, fine to medium-sized quartz grains and K-feldspar (more than 10\%). Quartz grains are mainly of igneous origin. Accessory minerals include titanite, zircon, mica along with chert and volcanic fragments.

\subsection{Shahrud-Gorgan road}

Two detrital samples were collected from the Devonian Padeha Formation along this section, representing two sandstone layers stratigraphically above the hiatus between member 1 and member 2 of the Padeha Formation (Fig. 5). One granitic clast was also sampled from the Padeha Member 1 conglomerates.

\subsubsection{Sample KS-12}

This is a whitish, medium-grained quartz arenite between the red shale units of member 2 of the Padeha Formation. This sample contains angular to rounded, medium-sized 
monocrystalline quartz grains. Quartz grains have volcanic (with straight extinction and embayment margins) and sedimentary (with overgrowths and hematite coating) origins (Aharipour et al., 2010). This sample contains heavy minerals including zircon and tourmaline along with chert fragments and microcline.

\subsubsection{Sample KS-8}

This sample is taken from an arkosic layer at the top of an $\sim 15 \mathrm{~m}$ thick arkosic arenite unit from member 2 of the Padeha Formation (Fig. 5). This sample contains abundant Kfeldspar (more than 25\%) along with quartz, tourmaline, and zircon grains and chert fragments. The sample is moderately- to well-sorted and mature. Arkosic sediments in this area may have formed in distal fan fluvial channels (Aharipour et al., 2010).

\subsubsection{Sample KS15-1}

This sample is a granitic pebble within the conglomerates at the base of member 1 Padeha Formation. These conglomerates lie on top of Soltan-Meidan basalts. The granitic clast contains abundant anhedral quartz crystals with coarse-grained orthoclase phenocrysts. Plagioclase is rare and perthitic intergrowths are abundant. These clasts contain minor chloritized biotites. The overall mineral characteristic resembles that of A-type granites.

\section{Results}

4.1. Detrital zircons from the Shirooyeh village sediments

\subsubsection{Sample G11-1}

Zircons from this sample of Late Ordovician Qelli Formation arkosic sandstone range in size between 70 and $150 \mu \mathrm{m}$. Most zircons are rounded or anhedral. In CL images, they show magmatic zoning or are unzoned. The unzoned zircons mostly have rounded shapes. We dated 90 zircon grains from this sample (Table 1). Eighty-four grains are concordant. The oldest grain yielded a 207Pb/206Pb age of $2577 \mathrm{Ma}$ (Supplementary 
Table 1). The weighted mean age of youngest coherent population is $484.5 \mathrm{Ma}$ (Table 1 ), a maximum depositional age that corresponds to Early Ordovician time.

The detrital zircon ages show a bimodal distribution with major NeoproterozoicEarly Paleozoic and minor Paleoproterozoic populations (Fig. 7A). The NeoproterozoicEarly Paleozoic populations have conspicuous age peaks at 773, 633, 554 and $492 \mathrm{Ma}$ (Fig. 7A). The main peak at $492 \mathrm{Ma}$ is consistent with Late Cambrian magmatism, perhaps related to early Gondwana rifting and Paleotethys opening.

\subsubsection{Sample G11-3}

Zircons from this sample of Late Ordovician Qelli Formation arkosic sandstone range in size between 50 and $100 \mu \mathrm{m}$. Most zircons are rounded or anhedral. In CL images, they are zoned or unzoned, but do not show metamorphic rims. We dated 76 points on 73 grains from this sample (Table 1). Seventy analyses are concordant. The oldest grain yielded a $207 \mathrm{~Pb} / 206 \mathrm{~Pb}$ age of $3129 \mathrm{Ma}$ (Supplementary Table 1). The weighted mean age of the youngest coherent population is $440 \mathrm{Ma}$ (Table 1), a maximum depositional age that corresponds to Early Silurian time. This $\mathrm{U}-\mathrm{Pb}$ result shows that the age of the Qelli Formation should be revised, and suggests that these sediments were deposited from Early Ordovician to Early Silurian time.

The detrital zircon ages show a bimodal distribution with major NeoproterozoicEarly Paleozoic and minor Paleoproterozoic populations (Fig. 7B). The NeoproterozoicEarly Paleozoic populations have conspicuous age peaks at 830, 608 and 457 Ma (Fig. 7). The main peak at $457 \mathrm{Ma}$ is consistent with Late Ordovician magmatism, again perhaps related to rifting and opening of Paleotethys.

\subsubsection{Sample GP-9}

Zircons from this sample of quartz arenite from the Devonian Padeha Formation range in size from 100 and $150 \mu \mathrm{m}$; they are subhedral to euhedral and some are rounded. In CL images, rounded zircons are unzoned whereas euhedral to subhedral zircons show oscillatory and patchy zonation typical of magmatic zircons (Corfu, 2004; Corfu et al., 2003). Some zircons have cores with thick rims that are either unzoned or oscillatory zoned. One hundred forty eight grains were analyzed for $\mathrm{U}-\mathrm{Pb}$ dating and among them 133 zircons are concordant. The weighted mean age of youngest coherent population is 
$517 \mathrm{Ma}$ (Middle Cambrian; Table 1). The oldest grain has a $207 \mathrm{~Pb} / 206 \mathrm{~Pb}$ age of $\sim 2680$ Ma. This sample has main age populations at Early Neoproterozoic-Early Cambrian ( 514-1000 Ma) and Neoarchean ( 2494-2524 Ma), with a minor Paleoproterozoic peak ( $\sim 1846 \mathrm{Ma})$. Two Ediacaran peaks ( $\sim 556$ and $\sim 621 \mathrm{Ma})$ and a Cryogenian $(\sim 796$ Ma) peak are especially conspicuous (Fig. 7C). The $\sim 450$ Ma peak that dominates the G11-3 spectrum is not seen, but an Early Cambrian peak (514 Ma) is dominant.

\subsubsection{Sample GP-12}

Most zircons in this feldspathic wacke from the uppermost Padeha Formation are b100 $\mu \mathrm{m}$ long and rounded. In CL images they show complex zoning and core-and-rim structures are common. A few cores (3)were dated which show Archaean inheritance $(\sim 2.5 \mathrm{Ga})$. We analyzed 57 points on 54 grains and 45 analyses are concordant (Table 1$)$. The weighted mean age of the youngest coherent population is $516 \mathrm{Ma}$ (Middle Cambrian; Table 1). The $\sim 450$ Ma peak that dominates the G11-3 spectrum is not seen. Major age populations are Middle Cambrian (ca. $511 \mathrm{Ma}$ ), Ediacaran (573 and $626 \mathrm{Ma}$ ), Cryogenian (794 Ma) and Tonian-Stenian (851-1019 Ma), along with several small Paleoproterozoic-Neoarchean groups ( 2100-2500 Ma) (Fig. 7D). This sample also has a modest number of "Grenville"-aged ( $1000 \mathrm{Ma})$ detrital zircons.

\subsection{Detrital zircons from Shahrud-Gorgan road sediments}

\subsubsection{Sample KS-8}

Zircons in this sample of Devonian Padeha Formation arkosic arenite are mostly 100$150 \mu \mathrm{m}$ long and vary from unzoned and rounded to subhedral and oscillatory-zoned. Some zircons have dark cores and luminescent to bright, thick to thin rims. One hundred fifty-six points were analyzed and 133 analyses are concordant. The weighted mean age of youngest coherent population is $424 \mathrm{Ma}$ (Middle Silurian; Table 1), which is older than the expected sedimentation age of the Padeha Formation. This sample shows a complicated age distribution with a modest peak as young as $422 \mathrm{Ma}$ (Late Silurian). The largest age peaks are at 536 and $607 \mathrm{Ma}$ (Ediacaran), 733 and $764 \mathrm{Ma}$ (Cryogenian), 914-1013 Ma (Tonian-Stenian) and 2513- 2700 Ma (Neoarchean) (Fig. 7E). A few grains are Mesoproterozoic-Paleoproterozoic ( 1500-2200 Ma). This sample has a 
significant proportion of "Grenvillian"-aged detrital zircons. The oldest grain has a $207 \mathrm{~Pb} / 206 \mathrm{~Pb}$ age of $\sim 3085 \mathrm{Ma}$.

\subsubsection{Sample KS-12}

This sample of Devonian Padeha Formation quartz arenite contains 100-200 $\mu \mathrm{m}$ prismatic and oscillatory-zoned zircons. Their shapes and structures are similar to zircons from A-type granitic clasts in the Soltan-Meidan conglomerates (see next section). Rounded and unzoned zircons are rare. We dated 152 zircon grains and used 149 concordant grains for provenance interpretation (Table 1). The weighted mean age of youngest coherent population is $404 \mathrm{Ma}$ (Early Devonian). The major peak is at ca $435 \mathrm{Ma}$ (late Early Silurian), with a subordinate peak at 640 Ma (Late Cryogenian). In addition, this sample has a minor amount of Early Paleoproterozoic and Cadomian detrital zircons (Fig. 7F).

4.3. Magmatic zircons from A-type granitic pebbles (sample KS15-1)

Zircon grains in the A-type granitic pebbles are prismatic to stubby, with lengths of 100 to $200 \mu \mathrm{m}$. In CL images, most grains showmagmatic zoning. Eighteen spots were analyzed (Supplementary Table 2). The zircons have variable, but low U (70-305 ppm) and Th (34-274 ppm) contents, with $\mathrm{Th} / \mathrm{U}=0.48-0.89$. Most zircons are low in common $\mathrm{Pb}$, with value of f206 b $0.4 \%$ (Supplementary Table 2). All analyses are concordant within analytical errors (MSWD of concordance $=0.26$ ) (Fig. 8). A Concordia age of 441.0 $\pm 3.1 \mathrm{Ma}$ is obtained, which is interpreted as the crystallization age for the A-type granitic pebbles.

\subsection{Zircon Hf isotopes.}

To discuss the Lu-Hf isotope characteristics of each age population, we grouped the $\mathrm{EHf}$ $(\mathrm{t})$ values of detrital zircons according to their $\mathrm{U}-\mathrm{Pb}$ ages. The $176 \mathrm{Hf} / 177 \mathrm{Hf}(\mathrm{t})$ values of Archean-Paleoproterozoic zircons ( 2.7-1.8 Ga) vary between 0.28134 and 0.28100 , corresponding to $\varepsilon \mathrm{Hf}(\mathrm{t})=+5.4$ to -15 , suggesting both juvenile and reworked crustal sources. It is worth noting that 2.7-1.8 Ga detrital zircons from Tauride Neoproterozoic sediments show variable $\varepsilon H f$ values, ranging from +5 to -21 (Abbo et al., 2015)). 
Early Paleoproterozoic to Mesoproterozoic ( 1.6-1 Ga) detrital zircons have very variable $\varepsilon H f(t)$ values $(+10.5$ to -23.7$)$, but most are negative with $\mathrm{TDM}=3.4-1.2 \mathrm{Ga}$, suggesting the involvement of crustally-derived magmas as a source of detrital zircons.

The $176 \mathrm{Hf} / 177 \mathrm{Hf}(\mathrm{t})$ values of Neoproterozoic populations (990-605 Ma) range between 0.28272 and 0.28140 . Their $\varepsilon H f(t)$ varies over 40 epsilon units; from +12.6 to -28.4 (Supplementary Table 3). Half of these zircons have $\varepsilon H f(t)$ values higher than +4 , indicating a juvenile source similar to magmatic rocks from the Arabian-Nubian Shield (Ali et al., 2010, 2012; Stern, 2008; Stern et al., 2012) (Fig. 9). On the other hand, half of these zircons have low positive $(b+4)$ as well as negative $\varepsilon H f(t)$, with TDM $=\sim 3-1.2 \mathrm{Ga}$ (Fig. 9), suggesting that their sources involved reworked older crust.

Ediacaran-Early Cambrian ( 600-500 Ma) zircons have variable 76Hf/177Hf(t) values, ranging from 0.28271 to 0.28207 , corresponding to $\varepsilon H f(t)$ values of +9.4 and -13.1. Most zircons have $\varepsilon H f(t)$ values lower than $\sim+4$, giving TDM $=\sim 2-1.2$ Ga (Fig. 9). The low $\varepsilon H f(t)$ values of Cadomian-aged detrital zircons, characteristic of crustal reworking, suggest an Andean-type margin as the source of these detrital zircons. On the other hand, zircons with $\varepsilon H f(t)$ values higher than +4 show a more juvenile crustal or mantle source.

Late Cambrian-Early Devonian (499-412 Ma) detrital zircons have $176 \mathrm{Hf} / 177 \mathrm{Hf}(\mathrm{t})$ values between 0.28267 and 0.28239 , corresponding to $\varepsilon \mathrm{Hf}(\mathrm{t})$ values of +6.3 to -3.6 . More than half of these detrital zircons have positive $\varepsilon H f(t)$ values higher than +2.3 , whereas the rest have values as low $a s b+1.8$.

The $\varepsilon H f(t)$ values of zircons from A-type granitic pebbles range from +8.2 to +2.5 (Fig. 9). TDM1 ages (single-stage Hf-isotope model age assuming that the sample was derived from depleted mantle) vary from1.1-1.6 Ga whereas TDM2 (two-stage Hfisotopemodel age assuming that the sample was derived via the lower crust, separated from depleted mantle) range between 0.8 and $1.1 \mathrm{Ga}$ for the A-type granite (Supplementary Table 4).

For comparison we have plotted all $\mathrm{U}-\mathrm{Pb}-\mathrm{Hf}$ data on the magmatic and detrital zircons from Late Neoproterozoic magmatic rocks and Late Neoproterozoic-Paleozoic strata of Iran, Turkey (Taurides), Arabian- Nubian Shield and Iberian terranes (Fig. 9). The Cadomian (0.6-0.5) detrital zircons from this study show definite $\varepsilon H f(t)$ similarities with both magmatic and detrital zircons (of similar age) from Iran and other Cadomian terranes in north Gondwana. 


\section{Discussion}

We have identified seven significant age peaks from our studies of Ordovician and Devonian sediments in NE Iran: $2.5 \mathrm{Ga}, \sim 772 \mathrm{Ma}, 623 \mathrm{Ma}, 555 \mathrm{Ma}, 492 \mathrm{Ma}$ and $450 \mathrm{Ma}$ as well as a minor peak at 1019 Ma (Fig. 10). Not all of these peaks are seen in all samples, and the size of the peaks varies from sample to sample; for the discussion below we focus on the composite spectrum shown in Fig. 7G. What do these distinctive peaks reveal about the geologic evolution of Iran? Some of these zircons may be derived from erosion of local crust but some have no known sources in Iran. Below we use this new information in tandem with what is known about crustal tracts in the region to consider four topics: the provenance of pre-Cadomian detrital zircons, the provenance of Cadomian zircons, the provenance of Paleozoic sediments, and the implications of these results for the Early Paleozoic reconstruction of Iran.

\subsection{Provenances of pre-Cadomian detrital zircons}

The major peaks of Neoproterozoic-aged zircons are at 772 and $623 \mathrm{Ma}$ (Fig. 10). The younger detrital zircons (with peak at $623 \mathrm{Ma}$ ) might be derived from unroofing of latestage granitic rocks from the Arabian-Nubian shield (Ali et al., 2010; Avigad et al., 2015; Morag et al., 2011). Most detrital zircons with these ages have positive $\varepsilon H f(t)(\sim+13$ to +2) (Fig. 9), further supporting their derivation from ANS juvenile granitic rocks (with $\varepsilon H f(t)=+8.4$ to +4.5 ) (Ali et al., 2012, 2014). Some zircons have negative $\varepsilon H f(t)$, suggesting derivation from older crust reworked during the Neoproterozoic, like that of the Saharan Metacraton (Abdelsalam et al., 2002).

Other major populations of pre-Cadomian detrital zircons (with a major peak at $772 \mathrm{Ma}$ ) are consistent with derivation from other calc-alkaline, mantle-derived (juvenile) igneous rocks in the ANS (Ali et al., 2010), although more than half of the detrital zircons in this age population have negative $\varepsilon H f(t)$ values. Sources in eastern Arabia are also possible; this crust is Cryogenian and Tonian in age, although we have no Hf isotopic data (Stern and Johnson, 2010).

Detrital zircons with negative $\varepsilon H f(t)$ give 2.2-1.7 Ga model ages, suggesting the involvement of reworked Paleoproterozoic crust. Crust of this age has been recognized in the West African Craton (Linnemann et al., 2011) or these zircons may come from the poorly studied Saharan Metacraton. Detrital zircons older than $\sim 750$ Ma with positive 
eHf (t) values may be related to known Tonian-Cryogenian juvenile intra-oceanic arcmagmatismin the ANS associated with the closure of the Mozambique Ocean (Stern, 2002). This early arc-magmatic cycle in the ANS may also be recorded by detrital zircons from arc derived metasediments (ca 870-760 Ma) and magmatic zircons from orthogneisses as well as granitoids (ca 790-740 Ma) (Morag et al., 2011). Zircons from these early arc magmatic rocks (both granitoids and orthogneisses) have positive $\varepsilon H f(t)$ $(\sim+5)$, showing a juvenile mantle source, like other ANS magmatic rocks (Morag et al., 2011).

Detrital zircons from Paleozoic strata of NE Iran show another minor peak at $\sim 1019$ Ma (Stenian) with both positive and negative $\varepsilon H f(t)$ values, that might be sourced from basement like that found in a sliver of Sinai basement rocks. The existence of the Stenian magmatism in southern Sinai is demonstrated by the dominance of such detrital zircons with low $\varepsilon H f(t)$ values in Sa'al metasediments (Be'eri-Shlevin et al., 2009). Abundant detrital zircons of this age are also documented from Early Paleozoic sandstones from Libya and Jordan (Meinhold et al., 2013), so these could also be a source.

Another important population of detrital zircons in NE Iran is $\sim 2.5$ b.y. old (Fig. 10). These zircons have moderately high $\varepsilon H f(t)$ values; +5.4 to -15 . There is no known crust of this age in Iran or Anatolia. These old zircons may be sourced from the Saharan Metacraton (Abdelsalam et al., 2002) or from Afghanistan or Tarim. Archean to Paleoproterozoic igneous rocks occur sporadically in the Tarim block, and these rocks have positive $\varepsilon H f(t)$ values (Long et al., 2010; Ma et al., 2012). The basement of Afghanistan is also characterized by occurrences of Tonian-Stenian and ca $2.5 \mathrm{Ga}$ metamorphic rocks (Faryad et al., 2015). Abbo et al. (2015), Dorr et al. (2015) and Paquette and Le Pennec (2012) suggested that a high proportion of detrital and xenocrystic zircons with 2.5 to $1.0 \mathrm{Ga}$ ages, both in the Tauride and External Hellenides Neoproterozoic meta-sedimentary successions and in Neogene volcanics from the Eastern Mediterranean, reveal the presence of older "hidden" crustal vestiges along the Cadomian realm. This age peak is common in clastic sediments and so could be recycled from other sedimentary successions (Le Heron et al., 2013, 2015). In fact, the source of these old zircons is an enigma.

\subsection{Source of Cadomian zircons}


Detrital zircons from the Early Paleozoic detrital successions of NE Iran show another peak at $555 \mathrm{Ma}$, reflecting Cadomian magmatism in northern Gondwana. The Cadomian orogen reflects the subduction that formed the several thousand-kilometers long Cadomian-Avalonian arc along the northern margin of Gondwana (Garfunkel, 2015; Kroner and Romer, 2013). This belt stretches from Iberia through Central and SE Europe into Turkey and Iran (von Raumer et al., 2002); vestiges are found to the east in southern Tibet (e.g., (Ding et al., 2015; Hu et al., 2013)). Cadomian basement is also recently documented in northern Arabia (Stern et al., 2016; Thomas et al., 2015). Cadomian rocks make up the ancient crust of Iran. The oldest igneous rocks of Iran have ages of 600-500 Ma and have $\varepsilon H f(t)$ values between $\sim+18.7$ and -43.2 (Fig. 9a), indicating the importance of reworked older crust (Moghadam et al., 2015a). The $\varepsilon H f(t)$ values for the Cadomian-age detrital zircons that we have studied vary from +9.4 to -13.1 (Supplementary Table 3), encompassing the known range in the Cadomian basement of Iran. These detrital zircons are best explained as being derived from within Iran, although some could also have been derived from adjacent Cadomian blocks (such as the Taurides of Turkey or northern Arabia).

Our results suggest that the detrital zircons with ca 0.9-0.6 Ga ages originated from the ANS crust and those of 0.6-0.5 Ga belong to the local Cadomian magmatism in Iran and surroundings. However, there is no clear age gap between these two episodes of magmatism (with dominant peak at $\sim 0.6$ Ga (Fig. 10)). Morag et al. (2011)) reported the Hf-isotope compositions of detrital zircons from Cambrian-Ordovician sandstones at the northern tip of the ANS, in Israel and Jordan, and suggested that the zircons of ca 1000-550Ma ages with positive epsilon $\operatorname{Hf}(\mathrm{t})$ are from the ANS itself, while those with negative values are from distant reworked Gondwana sources. Although 0.6-0.5 Ga zircons could have been derived from the ANS and other reworked continental crust in Gondwana, it is reasonable to think that the abundant Cadomian basement rocks of Iran, with both positive and negative epsilon $\mathrm{Hf}(\mathrm{t})$ values (Fig. 9a), were the main sources for the detrital zircons in the sediments we studied. The variable epsilon $\mathrm{Hf}(\mathrm{t})$ values along with the shape of Cadomian-aged detrital zircons (euhedral to subhedral and nonrounded) further suggest that the local Cadomian terranes in Iran are the main sources of the Cadomian (0.6-0.5 Ga) detrital heavy minerals.

\subsection{Implications for Paleozoic sedimentary sources.}


Detrital zircon age populations of $\sim 492-404$ Ma (Late Cambrian to Early Devonian) probably record igneous activity related to the opening of Paleotethys near what is now NE Iran (Moghadam and Stern, 2014; Moghadamet al., 2015b). Ordovician alkaline gabbros and diorites associated with volcanic rocks (Soltan-Meidan Formation) are common in NE Iran and mark early stages of the rifting that opened Paleotethys (Moghadam et al., 2015b). Volcanic rocks of the Soltan-Meidan Formation vary from basalt to basaltic-andesite with transitional to alkaline natures (within-plate geochemical signature), and high contents of REEs, $\mathrm{Nb}$ and $\mathrm{Zr}$, which were suggested to originate from partial melting of a garnet peridotite mantle source within a rift-related tectonic setting (Derakhshi and Ghasemi, 2015).

The andesitic and basaltic lavas of the Qelli Formation north of Shirooyeh village are thought to be slightly older equivalents of the Soltan-Meidan basalts and suggest that the Paleozoic rifting-related magmatic activities started earlier in northeastern Iran. Unfortunately, there are not yet any geochemical studies on these volcanic rocks. The zircon $\varepsilon H f(t)$ values from A-type granitic pebbles range from +8.2 to +2.5 , which is consistent with melts derived from an enriched mantle source. U-Pb ages of zircon and baddeleyite from the gabbroic rocks are middle Ordovician, between 465 and $463 \mathrm{Ma}$ with slightly older inherited cores (480-470 Ma) (Shafaii Moghadam et al., unpublished data). A-type granitic pebbles within conglomerate member 1 of the Padeha Formation show Early Silurian ages of 441 Ma (Fig. 8). Undated mafic to intermediate sill-like intrusions are also abundant in the Cambrian Lalun and Mila formations of NE Iran. Such Late Cambrian- Silurian intrusive rocks in NE Iran are likely sources of 492-404 Ma detrital zircons.

The Paleozoic age populations of detrital zircons range from $492 \mathrm{Ma}$ to $404 \mathrm{Ma}$ (peak at $450 \mathrm{Ma}$ ), incidentally overlapping with A-type granite ages of $441 \mathrm{Ma}$ (Early Silurian). Therefore, the youngest age peak of ca $0.4 \mathrm{Ga}$, along with the age of A-type granites, is interpreted to represent Gondwana rifting and the opening of Paleotethys, which probably started in Ordovician time. The middle Paleozoic sedimentary rocks, both sandstones and micro-conglomerates of Ghelli and Padeha Formations, contain magmatic clasts similar to gabbros, volcanic rocks and especially A-type granites, confirming that such rocks were exposed at this time and were able to contribute detritus to sediments.

Detrital zircons with younger ages (Early Devonian) could be related to Paleotethys intra-oceanic subduction and continental-type magmatism on the nearby 
Turan plate (Eurasia) (Ghazi et al., 2001; Moghadam and Stern, 2014; Moghadam et al., 2015b; Zanchetta et al., 2013), but it is unlikely that such zircons could be transported across Paleo-Tethys to be deposited in Iran. The $\varepsilon H f(t)$ values of the Ordovician-Silurian detrital zircons $(+6.3$ to -3.6$)$ are similar to those of Ordovician-Silurian alkaline gabbros (Shafaii Moghadam et al., unpublished data) and A-type granitic fragments (this study) ( $\varepsilon H f(t)=+8.2$ to +2.5$)$. Zircons from Paleotethyan ophiolitic gabbros and plagiogranites have higher $\varepsilon H f(t)(+14.9$ to +13.8 , (Moghadam et al., 2015b)), so these rocks are unlikely to be the source of the Devonian detrital zircons. Therefore we conclude that Ordovician-early Devonian detrital zircons have mostly local sources.

Fig. 7 also indicates that the stratigraphically lower sandstones in the Qelli Formation (sample G11-1) contain a major zircon age peak at $492 \mathrm{Ma}$, compared to sample G11-3 (stratigraphically upper sample) with a major peak at 457Ma, showing that the older sandstones picked up detrital sediments from older, Early Cambrian magmatic rocks. Our field observations show that the older strata (such as the Lalun and Mila formations) in NE Iran contain abundant sill-like intrusions, which might have supplied the $\sim 490$ Ma detrital zircons. The Padeha sandstones in the Shirooyeh section lack a major peak at $\sim 0.4 \mathrm{Ga}$, but are dominated by $0.5 \mathrm{Ga}$ detrital zircons, suggesting that Cadomian basement rocks were locally uplifted during Early Devonian time. For the Shahrud-Gorgan road section, sample KS-12 (lower part of the Padeha Formation) shows a peak at $435 \mathrm{Ma}$, close to the age of A-type granitic pebbles ( 441 Ma).

\subsection{Implications for an Early Paleozoic reconstruction of Iran}

In recent years many attempts have focused on evaluating the relative abundance of zircon populations extracted from Late Neoproterozoic to Paleozoic sediments of northern Gondwana, including studies of Iberia (Balintoni et al., 2009; Fernandez et al., 2010; Fernandez-Suarez et al., 2014; Gutierrez-Alonso et al., 2003; Orejana et al., 2015) and the Arabian-Nubian Shield (Allen, 2007; Andresen et al., 2014; Avigad et al., 2003, 2007, 2012; Morag et al., 2012) but rarely for Iran and the Taurides of Anatolia (Abbo et al., 2015; Horton et al., 2008; Ustaömer et al., 2012). Our results define a spectrum of detrital zircon populations that is quite similar to those already defined in other sedimentary sequences from Cadomian fragments of northern Gondwana, including SW Eurasia, N. Africa, and Arabia (Fig. 11). Excepting the strong $~ 0.4$ Ga peak which reflects local sources, the detrital zircon populations of NE Iran are dominated by 
Neoproterozoic sources, especially those between 0.8-0.5 Ga in age, with lesser populations of older Tonian and Stenian (0.8-1 Ga) and Paleoproterozoic (2.2-1.8 Ga) age and a significant peak in Neoarchean-Paleoproterozoic time (ca $2.5 \mathrm{Ga}$ ). The other main differences between the Taurides, Arabia, Iberia and Iran are a major peak at $0.6 \mathrm{Ma}$, but a lack of age populations at $0.5 \mathrm{Ga}$ in the Taurides, Arabia and Iberia compared to Iran (Fig. 11). There is no doubt about the lack of $0.5 \mathrm{Ga}$ age populations in Arabia and Iberia, because detrital zircons were just sampled from Late NeoproterozoicEarly Cambrian sedimentary rocks in these regions. Abbo et al. (2015) reported a major peak at $630 \mathrm{Ma}$ for detrital zircons from Ediacaran sediments of the Taurides, and argued that $\sim 630$ Ma zircons with positive $\varepsilon H f(t)$ values may have originated from latestage granitoids of the Arabian-Nubian Shield.

However, the abundance of Late Neoproterozoic-Early Cambrian (Cadomian) granites in Iran resembles other Gondwana-related fragments (such as Taurides and Iberia) and similarities in $\varepsilon H f(t)$ values of magmatic zircons between these terranes reinforce the conclusion that Iberia, Arabia, Iran and Taurides were parts of the greater Gondwana supercontinent during Neoproterozoic time. The source of the most dominant detrital zircons in Late Neoproterozoic sediments of Iberia and Taurides is suggested to be in Afro-Arabian, which at that time also was part of northern Gondwana (Abbo et al., 2015; Avigad et al., 2016). Transport of Neoproterozoic ( 1.0-0.5 Ga) and older detrital sediments from Gondwana was toward the north-northeast, in terrestrial and marine super-fan systems (Meinhold et al., 2013). The great abundance of $0.5 \mathrm{Ga}$ detrital zircons in Iran and the lack of them in the Taurides might suggest that Cadomian basement was tectonically uplifted and exposed in Iran but not in Turkey. The greater abundance of 0.6 Ga detrital zircons in the Taurides and Iberia supports the idea that these continental fragments were located in the vicinity of the Arabian-Nubian Shield (northern Gondwana) during Late Neoproterozoic time. The maximum age of sedimentation in the Tauride Neoproterozoic basin is estimated as ca $580 \mathrm{Ma}$, which is slightly older than the oldest known Cadomian rock in Iran (Abbo et al., 2015). Therefore, the scarcity of Cryogenian detrital zircons in Iran compared to Arabia and Taurides, coupled with the greater abundance of Cadomian detrital zircons, suggests that Cadomian igneous rocks of Iran were the source of the sediments in the Iranian Paleozoic basins. On the other hand, the dominance of 2.5 Ga detrital zircons in Paleozoic sediments of this study suggests that some sediments were supplied from farther away to the east and west, e.g. Saharan Metacraton, Afghanistan and Tarim. 
Following the assembly of the Gondwana supercontinent, which started in Cryogenian and Ediacaran time (Collins and Pisarevsky, 2005), Neoproterozoic-Early Cambrian Cadomian arc-type magmatism occurred for several thousand kilometers along the north-northeast periphery of Gondwana including Iran, Turkey and Iberia (Abbo et al., 2015; Linnemann et al., 2008, 2014; Moghadam et al., 2015a; Orejana et al., 2015; Pereira et al., 2011; Ustaömer et al., 2009; Yilmaz Şahin et al., 2014). It is suggested that most peri-Gondwanan terranes along the Cadomian belt might have formed as back-arc or retro-arc basins, where sediments of Cadomian age were deposited (Nance and Murphy, 1994) (Fig. 12). Although the Cadomian episode in Iran, Turkey, Iberia and Arabia was a time of arc-type magmatism, Middle to Late Cambrian seems to have been a time of uplift and erosion of these arcs, accompanied by the development of a continental river system and deposition of huge volumes of detrital sediments. In Late Cambrian-Early Ordovician time, Iran and parts of Turkey (such as Taurides) and other blocks such as Afghanistan, Lhasa and Tarim were parts of the Gondwana supercontinent, whereas more western parts of Gondwana such as Iberia and parts of Turkey (such as Pontides) seem to have separated from Gondwana during opening of the Rheic back-arc oceanic basin (Stampfli, 2000; Stampfli et al., 1991).

In Late Cambrian-Early Ordovician time (ca 490-480 Ma), following uplift, rifting and magmatism in northern Gondwana, Paleotethys started to open (Fig. 12), and then further to the northeast the Tarim, Afghanistan and Lhasa blocks were detached. Early Ordovician magmatism was responsible for juvenile rift-related magmatism in NE Iran (basalts, A-type granites and alkaline gabbros), which were the main sources of $\sim 0.4 \mathrm{Ga}$ detrital zircons in the sedimentary rocks of NE Iran. The paucity of Ordovician detrital zircons in Turkey may showthat the rifting and opening of Paleotethys occurred predominantly in NE Iran, and/or Turkey was detached from Gondwana earlier, i.e., during opening of the Rheic Ocean. However, there are some Ordovician igneous rocks in NW Turkey, for example, $\sim 460$ Ma in the Sakarya Zone of Pontides (Özmen and Reischmann, 1999) and 446 Ma in Tavsanli Zone (Ozbey et al., 2013). These intrusions might be equivalent to those found in the Bohemian-Armorican massifs to the west (e.g., 492 Ma Milchberg granite; (Linnemann et al., 2014)). Further studies are needed to unravel the occurrence or absence of Ordovician magmatic rocks and/or Ordovician detrital zircons in Turkey, to test this hypothesis. 


\section{Conclusions}

$\mathrm{U}-\mathrm{Pb}$ geochronology of detrital zircons from six sandstones from NE Iran provides new constraints on the crustal evolution and paleotectonic reconstruction of Iran. Our detrital zircons define main populations at $\sim 2.5 \mathrm{Ga}, \sim 0.8-0.6 \mathrm{Ga}, 0.5 \mathrm{Ga}$ and $\sim 0.5-0.4 \mathrm{Ga}$. The age peak at 2.5 Ga does not correspond to any known outcrops of Archean rocks in Iran, and it may be useful to continue to search for such basement. The 0.8-0.6 Ga age populations with juvenile Hf-isotope signatures provide evidence for transport of clasticmaterial from the Arabian-Nubian Shield before Iran rifted away from Gondwana in Early Paleozoic time.

The results of this study provide newconstraints on tectono-magmatic events associated with the assembly and partial (northern) breakup of Gondwana supercontinent during 0.8-0.5 Ga and 0.5-0.4 Ga, respectively. Gondwana breakup and rifting during 0.5-0.4 Ga led to detachment of the Asiatic Hunic terranes from the Gondwana supercontinent. The imprints of Cadomian magmatism in Iran and Taurides confirm that these blocks were parts of Gondwana supercontinent during Late Neoproterozoic time.

\section{Acknowledgments}

This is contribution 825 from the ARC Centre of Excellence for Core to Crust Fluid Systems (http://www.ccfs.mq.edu.au) and 1090 in the GEMOC Key Centre (http://www.gemoc.mq.edu.au). The analytical data were partially obtained using instrumentation funded by DEST Systemic Infrastructure Grants, ARC LIEF, NCRIS/AuScope, industry partners and Macquarie University. This work was also partially funded by Chinese Academy of Sciences President's International Fellowship Initiative (PIFI) - grant No. 2015VEC063 - to the first author. GM was supported by the German Academic Exchange Service (DAAD). All logistical support for field studies came from Damghan University. This paper is published with the permission of the Geological Survey of Denmark and Greenland. We are very grateful to Avishai Abbo and two anonymous reviewers for their constructive reviews of the manuscript. Editorial suggestions by Sun-Lin Chung are appreciated. 


\section{References}

Abbo, A., Avigad, D., Gerdes, A., Güngör, T., 2015. Cadomian basement and Paleozoic to Triassic siliciclastics of the Taurides (Karacahisar dome, south-central Turkey): paleogeographic constraints from U-Pb-Hf in zircons. Lithos 227, 122-139.

Abdelsalam, M.G., Liegeois, J.P., Stern, R.J., 2002. The Saharan Metacraton. Journal of African Earth Sciences 34, 119-136.

Aharipour, R., Moussavi, M.R., Mosaddegh, H., Mistiaen, B., 2010. Facies features and paleoenvironmental reconstruction of the Early to Middle Devonian syn-rift volcanosedimentary succession (Padeha Formation) in the Eastern-Alborz Mountains, NE Iran. Facies 56, 279-294.

Ali, K., Andresen, A., Manton, W.I., Stern, R.J., Omar, S.A., Maurice, A.E., 2012. U-Pb zircon dating and $\mathrm{Sr}-\mathrm{Nd}-\mathrm{Hf}$ isotopic evidence to support a juvenile origin of the similar to $634 \mathrm{Ma}$ El Shalul granitic gneiss dome, Arabian-Nubian Shield. Geological Magazine $149,783-797$.

Ali, K.A., Stern, R.J., Manton, W.I., Kimura, J.I., Whitehouse, M.J., Mukherjee, S.K., Johnson, P.R., Griffin, W.R., 2010. Geochemical, U-Pb zircon, and Nd isotope investigations of the Neoproterozoic Ghawjah Metavolcanic rocks, Northwestern Saudi Arabia. Lithos $120,379-392$.

Allen, P.A., 2007. The Huqf Supergroup of Oman: basin development and context for Neoproterozoic glaciation. Earth-Science Reviews 84, 139-185.

Andresen, A., Abu El-Enen, M.M., Stern, R.J., Wilde, S.A., Ali, K.A., 2014. The Wadi Zaghra metasediments of Sinai, Egypt: new constraints on the late Cryogenian-Ediacaran tectonic evolution of the northernmost Arabian-Nubian Shield. International Geology Review 56, 1020-1038.

Avigad, D., Abbo, A., Gerdes, A., 2016. Origin of the Eastern Mediterranean: Neotethys rifting along a cryptic Cadomian suture with Afro-Arabia. Geological Society of America Bulletin B31370, 31371.

Avigad, D., Kolodner, K., McWilliams, M., Persing, H., Weissbrod, T., 2003. Origin of northern Gondwana Cambrian sandstone revealed by detrital zircon SHRIMP dating. Geology 31, 227-230.

Avigad, D., Weissbrod, T., Gerdes, A., Zlatkin, O., Ireland, T.R., Morag, N., 2015. The detrital zircon $\mathrm{U}-\mathrm{Pb}-\mathrm{Hf}$ fingerprint of the northern Arabian-Nubian Shield as 
reflected by a Late Ediacaran arkosic wedge (Zenifim Formation; subsurface Israel). Precambrian Research 266, 1-11.

Balaghi Einalou, M., Sadeghian, M., Zhai, M., Ghasemi, H., Mohajjel, M., 2014. Zircon U-Pb ages, Hf isotopes and geochemistry of the schists, gneisses and granites in Delbar Metamorphic-Igneous Complex, SE of Shahrood (Iran): implications for Neoproterozoic geodynamic evolutions of Central Iran. Journal of Asian Earth Sciences 92, 92-124.

Balintoni, I., Balica, C., Ducea, M.N., Chen, F.K., Hann, H.P., Sabliovschi, V., 2009. Late Cambrian-Early Ordovician Gondwanan terranes in the Romanian Carpathians: a zircon U-Pb provenance study. Gondwana Research 16, 119-133.

Be'eri-Shlevin, Y., Katzir, Y., Valley, J.W., 2009. Crustal evolution and recycling in a juvenile continent: oxygen isotope ratio of zircon in the northern Arabian Nubian Shield. Lithos 107, 169-184.

Berberian, M., King, G.C.P., 1981. Towards a paleogeography and tectonic evolution of Iran. Canadian Journal of Earth Sciences 18, 210-265.

Chauvel, C., Blichert-Toft, J., 2001. A hafnium isotope and trace element perspective on melting of the depleted mantle. Earth and Planetary Science Letters 190, 137-151.

Collins, A.S., Pisarevsky, S.A., 2005. Amalgamating eastern Gondwana: the evolution of the Circum-Indian Orogens. Earth-Science Reviews 71, 229-270.

Corfu, F., 2004. U-Pb age, setting and tectonic significance of the anorthositemangerite-charnockite-granite suite, Lofoten-Vesteralen, Norway. Journal of Petrology 45, 1799-1819.

Corfu, F., Hanchar, J.M., Hoskin, P.W.O., Kinny, P., 2003. Atlas of zircon textures. Zircon $53,469-500$.

Derakhshi, M., Ghasemi, H., 2015. Soltan Maidan Complex (SMC) in the eastern Alborz structural zone, northern Iran: magmatic evidence for Paleotethys development. Arabian Journal of Geosciences 8, 849-866.

Ding, H., Zhang, Z., Dong, X., Yan, R., Lin, Y., Jiang, H., 2015. Cambrian ultrapotassic rhyolites fromthe Lhasa terrane, south Tibet: evidence for Andean-type magmatism along the northern active margin of Gondwana. Gondwana Research 27, 16161629.

Dörr, W., Zulauf, G., Gerdes, A., Lahaye, Y., Kowalczyk, G., 2015. A hidden Tonian basement in the eastern Mediterranean: age constraints from $\mathrm{U}-\mathrm{Pb}$ data of 
magmatic and detrital zircons of the External Hellenides (Crete and Peloponnesus). Precambrian Research 258, 83-108.

Etemad-Saeed, N., Hosseini-Barzi, M., Adabi, M.H., Miller, N.R., Sadeghi, A., Houshmandzadeh, A., Stockli, D.F., 2015. Evidence for ca. 560 Ma Ediacaran Glaciation in the Kahar Formation, Central Alborz Mountains, Northern Iran. Gondwana Research.

Faryad, S.W., Collett, S., Finger, F., Sergeev, S.A., Čopjaková, R., Siman, P., 2015. The Kabul Block (Afghanistan), a Segment of the Columbia Supercontinent, With a Neoproterozoic Metamorphic Overprint. Gondwana Research.

Fernandez, R.D., Catalan, J.R.M., Gerdes, A., Abati, J., Arenas, R., Fernandez-Suarez, J., 2010. U-Pb ages of detrital zircons from the basal allochthonous units of NW Iberia: provenance and paleoposition on the northern margin of Gondwana during the Neoproterozoic and Paleozoic. Gondwana Research 18, 385-399.

Fernandez-Suarez, J., Gutierrez-Alonso, G., Pastor-Galan, D., Hofmann, M., Murphy, J.B., Linnemann, U., 2014. The Ediacaran-Early Cambrian detrital zircon record of NW Iberia: possible sources and paleogeographic constraints. International Journal of Earth Sciences 103, 1335-1357.

Garfunkel, Z., 2004. Origin of the Eastern Mediterranean basin: a reevaluation. Tectonophysics 391, 11-34.

Garfunkel, Z., 2015. The Relations Between Gondwana and the Adjacent Peripheral Cadomian Domain-Constrains on the Origin, History, and Paleogeography of the Peripheral Domain. Gondwana Research.

Ghavidel-syooki, M., 2006. Palynostratigraphy and palaeogeography of the CambroOrdovician strata in southwest of Shahrud City (Kuh-e-Kharbash, near Deh-Molla), Central Alborz Range, northern Iran. Review of Palaeobotany and Palynology 139, 81-95.

Ghavidel-syooki, M., Vecoli, M., 2007. Latest Ordovician-early Silurian chitinozoans from the eastern Alborz Mountain Range, Kopet-Dagh region, northeastern Iran: biostratigraphy and palaeobiogeography. Review of Palaeobotany and Palynology $145,173-192$.

Ghavidel-syooki, M., Winchester-Seeto, T., 2002. Biostratigraphy and palaeogeography of Late Ordovician chitinozoans from the northeastern Alborz Range, Iran. Review of Palaeobotany and Palynology 118, 77-99. 
Ghavidel-Syooki, M., Hassanzadeh, J., Vecoli, M., 2011. Palynology and isotope geochronology of the Late Ordovician-Silurian successions (Ghelli and Soltan Maidan Formations) in the Khoshyeilagh area, eastern Alborz Range, northern Iran; stratigraphic and palaeogeographic implications. Review of Palaeobotany and Palynology 164, 251-271.

Ghazi, M., Hassanipak, A.A., Tucker, P.J., Mobasher, K., 2001. Geochemistry and 40Ar39Ar ages of the Mashhad Ophiolite, NE Iran. Eos, Transactions of the American Geophysical Union 47.

Gutierrez-Alonso, G., Fernandez-Suarez, J., Jeffries, T.E., Jenner, G.A., Tubrett, M.N., Cox, R., Jackson, S.E., 2003. Terrane accretion and dispersal in the northern Gondwana margin. An Early Paleozoic analogue of a long-lived active margin. Tectonophysics $365,221-232$.

Hamdi, B., 1995. Precambrian, Cambrian Sedimentary Rocks in Iran. Geological Survey of Iran.

Hassanzadeh, J., Stockli, D.F., Horton, B.K., Axen, G.J., Stockli, L.D., Grove, M., Schmitt, A.K., Walker, J.D., 2008. U-Pb zircon geochronology of late Neoproterozoic-Early Cambrian granitoids in Iran: implications for paleogeography, magmatism, and exhumation history of Iranian basement. Tectonophysics 451, 71-96.

Henderson, B.J., Collins, W.J., Murphy, J.B., Gutierrez-Alonso, G., Hand, M., 2016. Gondwanan basement terranes of the Variscan-Appalachian orogen: Baltican, Saharan and West African hafnium isotopic fingerprints in Avalonia, Iberia and the Armorican Terranes. Tectonophysics 681, 278-304.

Horton, B.K., Hassanzadeh, J., Stockli, D.F., Axen, G.J., Gillis, R.J., Guest, B., Amini, A., Fakllari, M.D., Zamanzadeh, S.M., Grove, M., 2008. Detrital zircon provenance of Neoproterozoic to Cenozoic deposits in Iran: implications for chronostratigraphy and collisional tectonics. Tectonophysics 451, 97-122.

Hu, P.Y., Li, C., Wang, M., Xie, C.M., Wu, Y.W., 2013. Cambrian volcanism in the Lhasa terrane, southern Tibet: record of an early Paleozoic Andean-type magmatic arc along the Gondwana proto-Tethyan margin. Journal of Asian Earth Sciences 77, 91107.

Iizuka, T., Campbell, I.H., Allen, C.M., Gill, J.B., Maruyama, S., Makoka, F., 2013. Evolution of the African continental crust as recorded by $\mathrm{U}-\mathrm{Pb}, \mathrm{Lu}-\mathrm{Hf}$ and $\mathrm{O}$ isotopes in detrital zircons from modern rivers. Geochimica et Cosmochimica Acta 107, 96-120. 
Kroner, U., Romer, R.L., 2013. Two plates - many subduction zones: the Variscan orogeny reconsidered. Gondwana Research 24, 298-329.

Kröner, A., Şengör, A.M.C., 1990. Archean and Proterozoic ancestry in late Precambrian to early Paleozoic crustal elements of southern turkey as revealed by single-zircon dating. Geology 18, 1186-1190.

Le Heron, D.P., Meinhold, G., Bergig, K.A., 2013. Neoproterozoic-Devonian stratigraphic evolution of the eastern Murzuq Basin, Libya: a tale of tilting in the central Sahara. Basin Research 25, 52-73.

Linnemann, U., Gerdes, A., Hofmann, M., Marko, L., 2014. The Cadomian Orogen: Neoproterozoic to Early Cambrian crustal growth and orogenic zoning along the periphery of the West African Craton-constraints from U-Pb zircon ages and $\mathrm{Hf}$ isotopes (Schwarzburg Antiform, Germany). Precambrian Research 244, 236-278.

Linnemann, U., Ouzegane, K., Drareni, A., Hofmann, M., Becker, S., Gartner, A., Sagawe, A., 2011. Sands of West Gondwana: an archive of secular magmatism and plate interactions - a case study from the Cambro-Ordovician section of the Tassili Ouan Ahaggar (Algerian Sahara) using U-Pb-LA-ICP-MS detrital zircon ages. Lithos 123, 188-203.

Linnemann, U., Pereira, F., Jeffries, T.E., Drost, K., Gerdes, A., 2008. The Cadomian Orogeny and the opening of the Rheic Ocean: the diacrony of geotectonic processes constrained by LA-ICP-MS U-Pb zircon dating (Ossa-Morena and Saxo-Thuringian Zones, Iberian and Bohemian Massifs). Tectonophysics 461, 21-43.

Long, X.P., Yuan, C., Sun, M., Zhao, G.C., Xiao, W.J., Wang, Y.J., Yang, Y.H., Hu, A.Q., 2010. Archean crustal evolution of the northern Tarim craton, NW China: zircon $\mathrm{U}-\mathrm{Pb}$ and Hf isotopic constraints. Precambrian Research 180, 272-284.

Ludwig, K.R., 2003a. ISOPLOT 3.0: a geochronological toolkit for Microsoft Excel. Berkeley Geochronology Center Special Publications, p. 4.

Ludwig, K.R., 2003b. User's Manual for Isoplot 3.00: A Geochronological Toolkit for Microsoft Excel. p. 74.

Ma, X.X., Shu, L.S., Santosh, M., Li, J.Y., 2012. Detrital zircon U-Pb geochronology and Hf isotope data from Central Tianshan suggesting a linkwith the Tarim Block: implications on Proterozoic supercontinent history. Precambrian Research 206, 116. 
Meinhold, G., Morton, A.C., Avigad, D., 2013. New insights into peri-Gondwana paleogeography and the Gondwana super-fan system from detrital zircon $\mathrm{U}-\mathrm{Pb}$ ages. Gondwana Research 23, 661-665.

Moghadam, H.S., Stern, R.J., 2014. Ophiolites of Iran: keys to understanding the tectonic evolution of SW Asia: (I) Paleozoic ophiolites. Journal of Asian Earth Sciences 91, 19-38.

Moghadam, H.S., Khademi, M., Hu, Z.C., Stern, R.J., Santos, J.F., Wu, Y.B., 2015a. Cadomian (Ediacaran-Cambrian) arc magmatism in the ChahJam-Biarjmand metamorphic complex (Iran): magmatism along the northern active margin of Gondwana. Gondwana Research 27, 439-452.

Moghadam, H.S., Li, X.-H., Ling, X.-X., Stern, R.J., Khedr, M.Z., Chiaradia, M., Ghorbani, G., Arai, S., Tamura, A., 2015b. Devonian to Permian evolution of the Paleo-Tethys Ocean: new evidence from $\mathrm{U}-\mathrm{Pb}$ zircon dating and $\mathrm{Sr}-\mathrm{Nd}-\mathrm{Pb}$ isotopes of the Darrehanjir-Mashhad “ophiolites”, NE Iran. Gondwana Research 28, 781-799.

Morag, N., Avigad, D., Gerdes, A., Belousova, E., Harlavan, Y., 2011. Crustal evolution and recycling in the northern Arabian-Nubian Shield: new perspectives from zircon LuHf and U-Pb systematics. Precambrian Research 186, 101-116.

Morag, N., Avigad, D., Gerdes, A., Harlavan, Y., 2012. 1000-580 Ma crustal evolution in the northern Arabian-Nubian Shield revealed by U-Pb-Hf of detrital zircons from late Neoproterozoic sediments (Elat area, Israel). Precambrian Research 208, 197212.

Nance, R.D., Murphy, J.B., 1994. Contrasting basement isotopic signatures and the palinspastic restoration of peripheral orogens - example from the Neoproterozoic Avalonian-Cadomian Belt. Geology 22, 617-620.

Orejana, D., Martinez, E.M., Villaseca, C., Andersen, T., 2015. Ediacaran-Cambrian paleogeography and geodynamic setting of the Central Iberian Zone: constraints from coupled U-Pb-Hf isotopes of detrital zircons. Precambrian Research 261, 234251.

Ozbey, Z., Ustaomer, T., Robertson, A.H.F., Ustaomer, P.A., 2013. Tectonic significance of Late Ordovician granitic magmatism and clastic sedimentation on the northern margin of Gondwana (Tavsanli Zone, NW Turkey). Journal of the Geological Society $170,159-173$. 
Özmen, F., Reischmann, T., 1999. The age of the Sakarya continent in W Anatolia: implications for the evolution of the Aegean region. Journal of Conference Abstracts $4,805$.

Paquette, J.L., Le Pennec, J.L., 2012. 3.8 Ga zircons sampled by Neogene ignimbrite eruptions in Central Anatolia. Geology 40, 239-242.

Pereira, M.F., Chichorro, M., Sola, A.R., Silva, J.B., Sanchez-Garcia, T., Bellido, F., 2011. Tracing the Cadomian magmatism with detrital/inherited zircon ages by in-situ U$\mathrm{Pb}$ SHRIMP geochronology (Ossa-Morena Zone, SW Iberian Massif). Lithos 123, 204-217.

Ramezani, J., Tucker, R.D., 2003. The Saghand Region, Central Iran: U-Pb geochronology, petrogenesis and implications for Gondwana Tectonics. American Journal of Science $303,622-665$.

Robertson, A.H.F., Clift, P.D., Degnan, P.J., Jones, G., 1991. Paleogeographic and paleotectonic evolution of the eastern Mediterranean Neotethys. Palaeogeography Palaeoclimatology Palaeoecology 87, 289-343.

Shu, L., Deng, X., Zhu, W., Ma, D., Xiao, W., 2011. Precambrian tectonic evolution of the Tarim Block, NW China: new geochronological insights from the Quruqtagh domain. Journal of Asian Earth Sciences 42, 774-790.

Stampfli, G., 1978. Etude géologique generale de l'Elbourz oriental au sud de Gonbad-eQabus (Iran NE). Universite de Genève, p. 329.

Stampfli, G.M., 2000. Tethyan oceans. Geological Society, London, Special Publications $173,1-23$.

Stampfli, G., Marcoux, J., Baud, A., 1991. Tethyan margins in space and time. Palaeogeography, Palaeoclimatology, Palaeoecology 87, 373-409.

Stern, R.J., 2002. Crustal evolution in the East African Orogen: a neodymium isotopic perspective. Journal of African Earth Sciences 34, 109-117.

Stern, R.J., 2008. Neoproterozoic crustal growth: the solid Earth system during a critical episode of Earth history. Gondwana Research 14, 33-50.

Stern, R.J., Johnson, P., 2010. Continental lithosphere of the Arabian Plate: a geologic, petrologic, and geophysical synthesis. Earth-Science Reviews 101, 29-67.

Stern, R.J., Ali, K.A., Abdelsalam, M.G., Wilde, S.A., Zhou, Q., 2012. U-Pb zircon geochronology of the eastern part of the Southern Ethiopian Shield. Precambrian Research 206, 159-167. 
Stern, R.J., Ali, K.A., Ren, M., Jarrar, G.H., Romer, R.L., Leybourne, M.I., Whitehouse, M.J., Ibrahim, K.M., 2016. Cadomian ( $560 \mathrm{Ma})$ crust buried beneath the northern Arabian Peninsula: mineral, chemical, geochronological, and isotopic constraints from NE Jordan xenoliths. Earth and Planetary Science Letters 436, 31-42.

Stocklin, J., 1968. Structural history and tectonics of Iran, a review. AAPG Bulletin 52, 1229-1258.

Thomas, R.J., Ellison, R.A., Goodenough, K.M., Roberts, N.M.W., Allen, P.A., 2015. Salt domes of the UAE and Oman: probing eastern Arabia. Precambrian Research 256, $1-16$.

Ustaömer, P.A., Ustaömer, T., Collins, A.S., Robertson, A.H.F., 2009. Cadomian (Ediacaran-Cambrian) arc magmatism in the Bitlis Massif, SE Turkey: magmatism along the developing northern margin of Gondwana. Tectonophysics 473, 99-112.

Ustaömer, P.A., Ustaömer, T., Gerdes, A., Robertson, A.H.F., Collins, A.S., 2012. Evidence of Precambrian sedimentation/magmatism and Cambrian metamorphism in the Bitlis Massif, SE Turkey utilising whole-rock geochemistry and U-Pb LA-ICP-MS zircon dating. Gondwana Research 21, 1001-1018.

von Raumer, J., Stampfli, G., Borel, G., Bussy, F., 2002. Organization of pre-Variscan basement areas at the north-Gondwanan margin. International Journal of Earth Sciences 91, 35-52.

Wendt, J., Kaufmann, B., Belka, Z., Farsan, N., Bavandpur, A.K., 2005. Devonian/Lower Carboniferous stratigraphy, facies patterns and palaeogeography of Iran - part II. Northern and central Iran. Acta Geologica Polonica 55 (31-U22).

Yilmaz Şahin, S., Aysal, N., Güngör, Y., Peytcheva, I., Neubauer, F., 2014. Geochemistry and $\mathrm{U}-\mathrm{Pb}$ zircon geochronology of metagranites in Istranca (Strandja) Zone, NW Pontides, Turkey: implications for the geodynamic evolution of Cadomian orogeny. Gondwana Research 26, 755-771.

Zanchetta, S., Berra, F., Zanchi, A., Bergomi, M., Caridroit, M., Nicora, A., Heidarzadeh, G., 2013. The record of the Late Palaeozoic active margin of the Palaeotethys in NE Iran: constraints on the Cimmerian orogeny. Gondwana Research 24, 1237-1266. 


\section{Figure captions}

Fig. 1. Distribution of Neoproterozoic-Paleozoic sedimentary and igneous rocks in Iran (modified after 1/1,000,000 Geological Map of Iran, GSI).

Fig. 2. Stratigraphic chart of Iran for Kopet Dagh (Eastern Alborz), central Iran and Zagros zones from Neoproterozoic to Jurassic.

Fig. 3. Geological map north of the Shirooyeh village (modified after Geological map of Bojnurd, GSI) showing the sedimentary units relationships and sampling units.

Fig. 4. Geological map of Khosh Yeylagh Valley (modified after Geological map of Khosh Yeylagh, GSI) showing the sedimentary-volcanic rock relationships and sampling units.

Fig. 5. Stratigraphic sections of the studied areas showing sample locations and their relationships.

Fig. 6. A-Conglomerate unit of themember 1 Padeha Formation including plutonicvolcanic and sedimentary rocks fragments. B-A-type granitic pebbleswithin the conglomerate unit of member 1 Padeha Formation. C-Relationships between arkosic sandstones and quartz arenites inmember 2 Padeha Formation. D Alternation of red and green shale and graywacke in member 2 Padeha Formation.

Fig. 7. Density distribution diagrams of concordant zircon ages (90-110\% conc.) of the analyzed samples from Qelli and Padeha Formations.

Fig. 8. U-Pb concordia diagramfor magmatic zircons fromthe A-type granitic clasts within the member 1 Padeha Formation.

Fig. 9. Summary of $\varepsilon H f(t)$ values for detrital and magmatic zircons fromall sedimentary rocks and A-type granite studied versus their $\mathrm{U}-\mathrm{Pb}$ ages. The depletedmantle arraywas calculated using data from modern Mid-Oceanic Ridge basalts (Chauvel and Blichert-Toft, 2001). For comparison we plotted Hf isotope data on the 
magmatic and detrital zircons from other Cadomian fragments such as the Taurides (Abbo et al., 2015), Iberia-Avalonia-Armorica (Orejana et al., 2015) as well as Arabian-Nubian Shield (Morag et al., 2012). Data on the Iranian Cadomian magmatic zircons come from Moghadam et al. (unpublished data) and (Balaghi Einalou et al., 2014).

Fig. 10. Summary of detrital zircon age spectra of the NE Iran Paleozoic rocks versus the main tectono-magmatic events of Northern Gondwana-Iran.

Fig. 11. Probability plots for $\mathrm{U}-\mathrm{Pb}$ ages of detrital zircons fromIran, Arabian-Nubian Shield, Taurides, Iberia-Avalonia-Armorica, Africa and NE Tarim. Data taken from Abbo et al. (2015), Fernandez-Suarez et al. (2014), Henderson et al. (2016), Horton et al. (2008), Iizuka et al. (2013), Meinhold et al. (2013), Morag et al. (2012), Orejana et al. (2015) and Shu et al. (2011).

Fig. 12. Schematic diagram showing the Neoproterozoic-Early Cambrian and Late Cambrian-Ordovician tectonic setting of Iran and Afro-Arabia during deposition of the Cadomian and early Paleozoic sediments. a) Late Neoproterozoic-Early Cambrian sediments, sourced fromerosion of the nearby Cadomian arc, accumulated in amarine basin, on a denudated continental crust (proto-ensialic back-arc basin). b) Early Paleozoic magmatism, related to the early phases of Paleotethys rifting, supplied abundant 0.4 Ga detrital zircons in local sedimentary basins.

\section{Tables}

Table 1 . Summary of $\mathrm{U}-\mathrm{Pb}$ data from the NE Iran detrital zircons. 


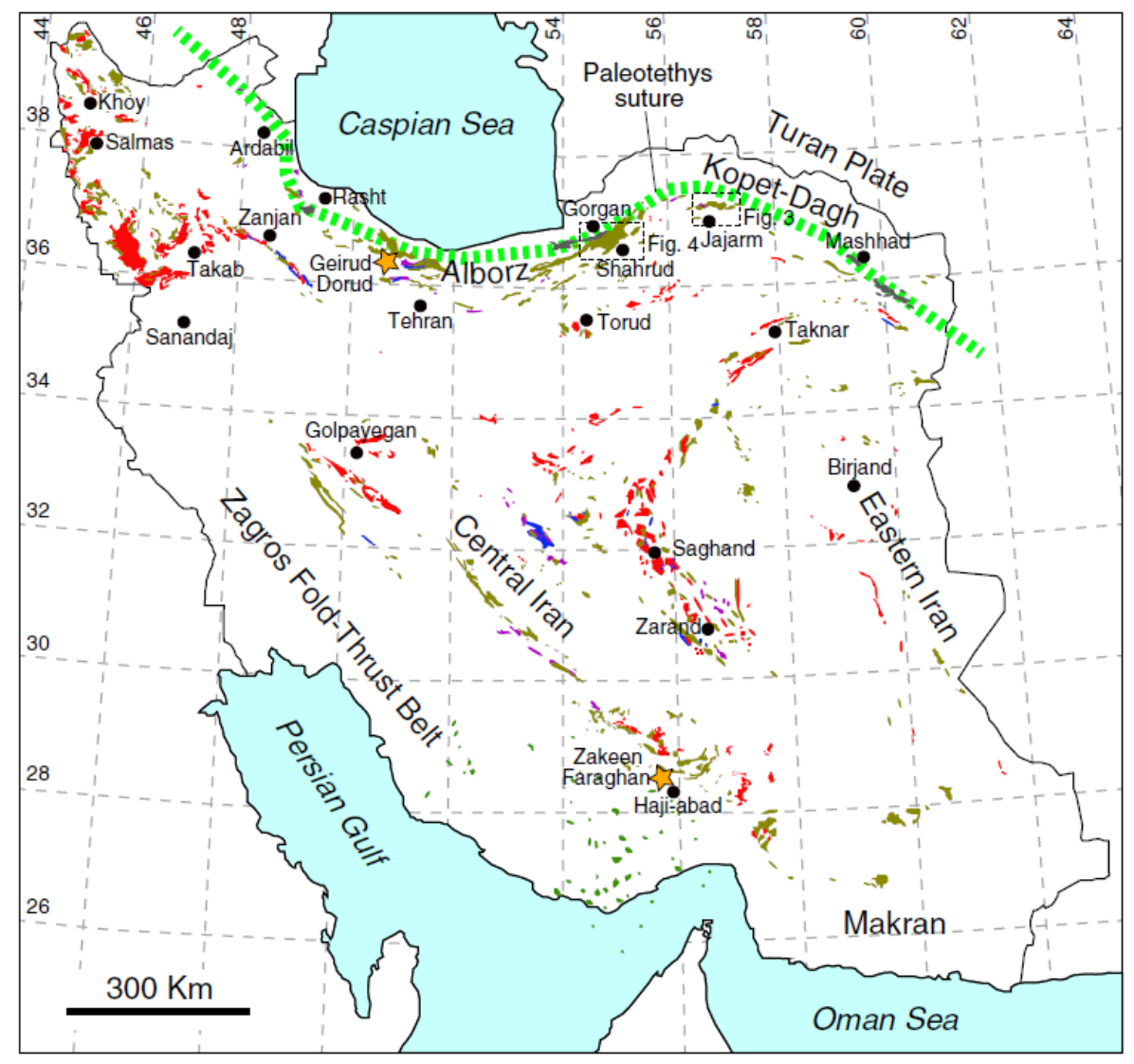

\section{LEGEND}

Paleozoic ophiolites

Paleozoic sedimentary rocks

Early Cambrian volcanosedimentary rocks

Late Neoproterozoic-Early Cambrian salt domes

Late Neoproterozoic-Early Cambrian sediments

Late Neoproterozoic-Early Cambrian meta-igneous ocks

is Sampling area by

Fig. 1 


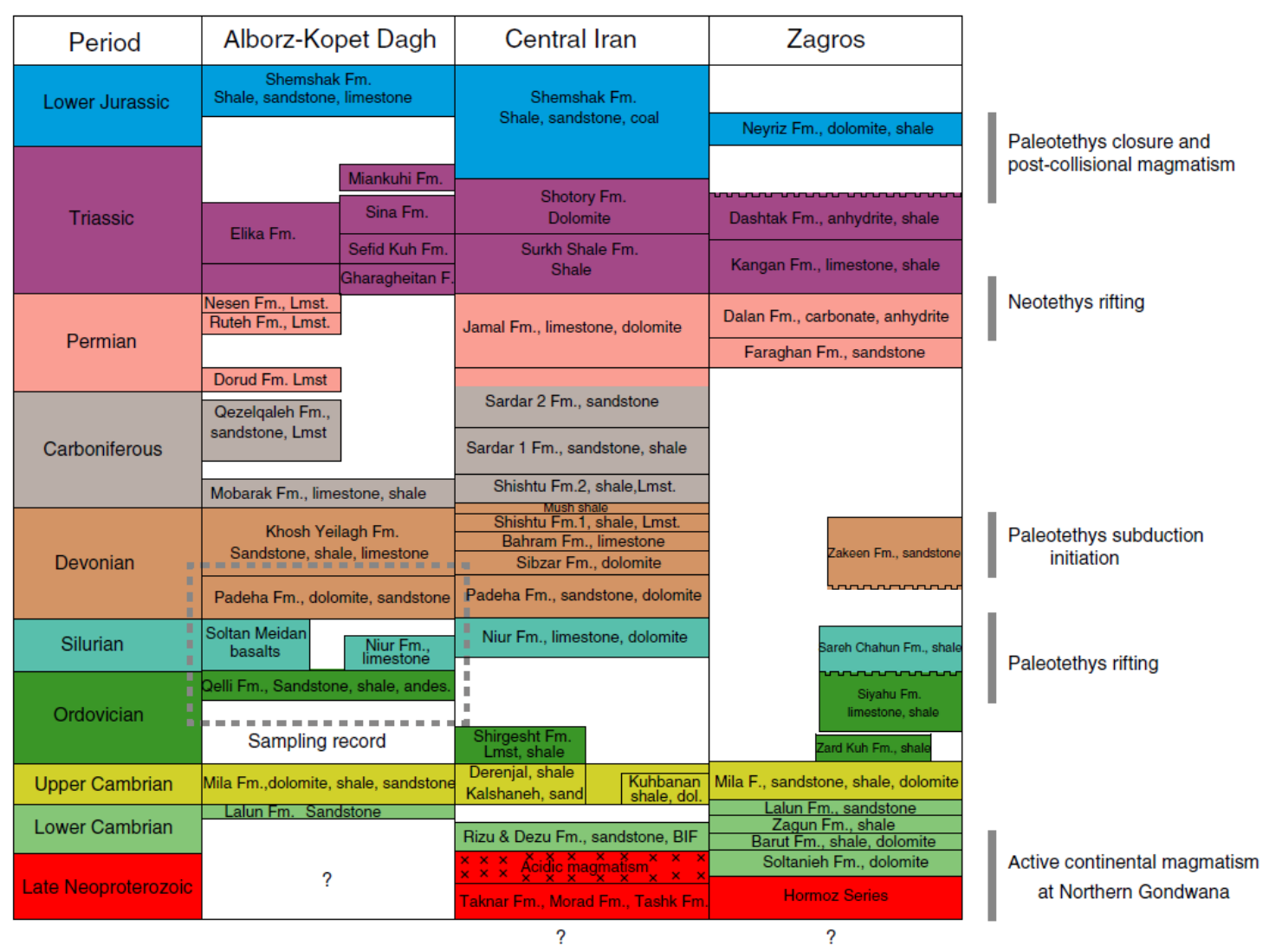

Fig. 2 


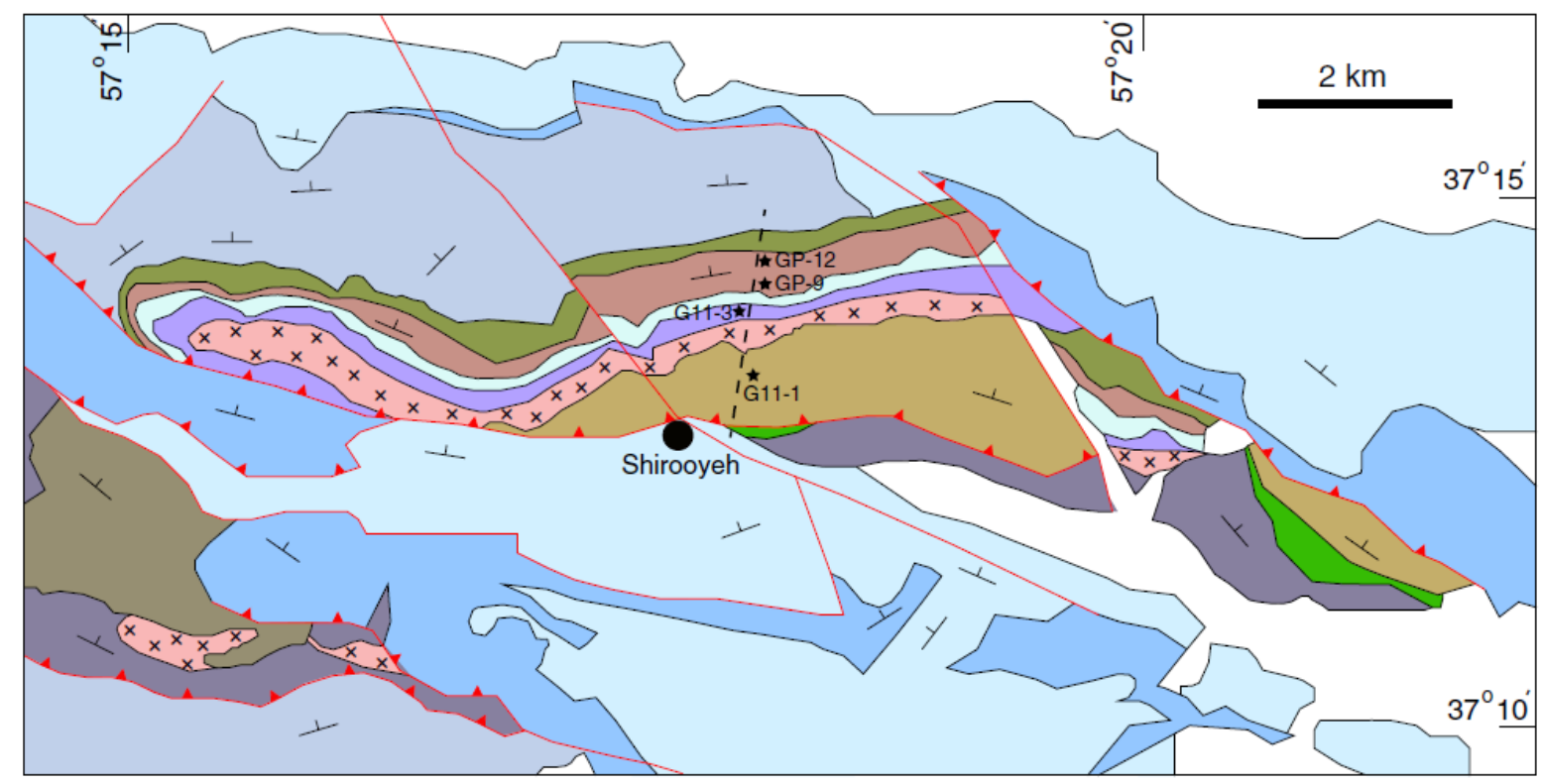

\begin{tabular}{|c|c|c|c|}
\hline &. & & Limestone, sandstone \\
\hline & E & & Shale, sandstone \\
\hline & $\stackrel{\square}{\square}$ & $x^{x} x^{x}$ & Volcanic rock \\
\hline & $\overline{\bar{\Phi}}$ & & Green shale, sandston \\
\hline & Mila Fm. & & $\begin{array}{l}\text { Sandstone, shale, } \\
\text { limestone }\end{array}$ \\
\hline & 타 & & Dolomite \\
\hline & 赵 & & Sandstone, shale \\
\hline
\end{tabular}

\begin{tabular}{|c|c|c|}
\hline$乃$ & Lar Fm. & Dolomitic Lmst \\
\hline 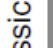 & Delichai Fm. & Limestone, marl \\
\hline D & $\begin{array}{c}\text { Kashaf Rud } \\
\text { Formation }\end{array}$ & Shale, sandstone \\
\hline$\frac{\bar{\sigma}}{\underline{c}}$ & $\begin{array}{c}\text { Khosh Yeylagh } \\
\text { Formation }\end{array}$ & Limestone, shale \\
\hline ষ & Padeha Fm. & $\begin{array}{l}\text { Sandstone, marly } \\
\text { shale }\end{array}$ \\
\hline
\end{tabular}

Fig. 3 


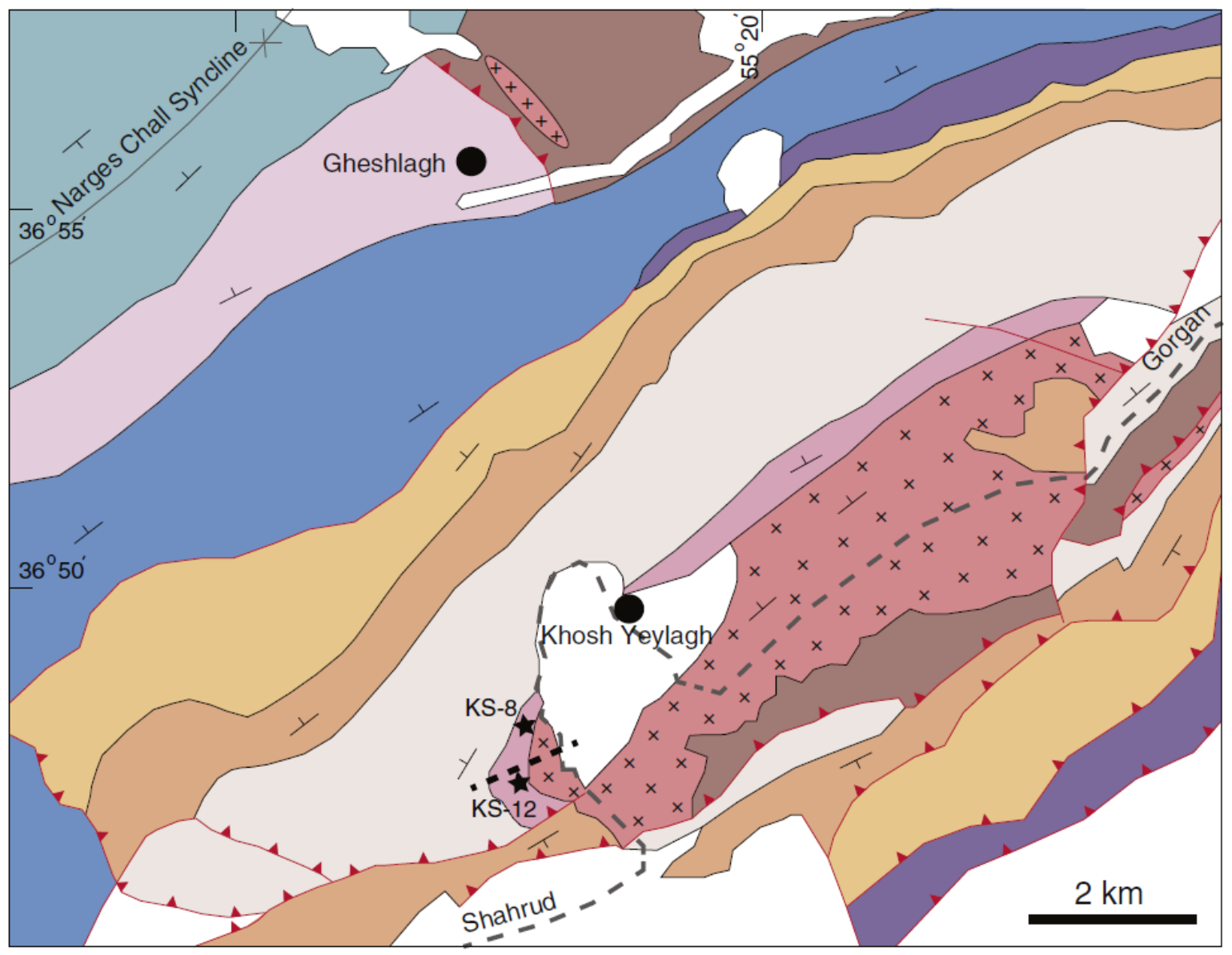

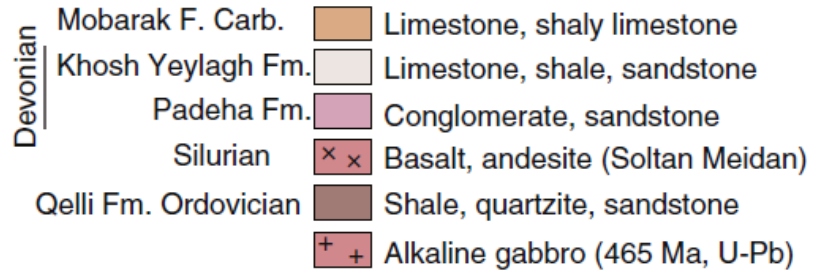

Fig. 4

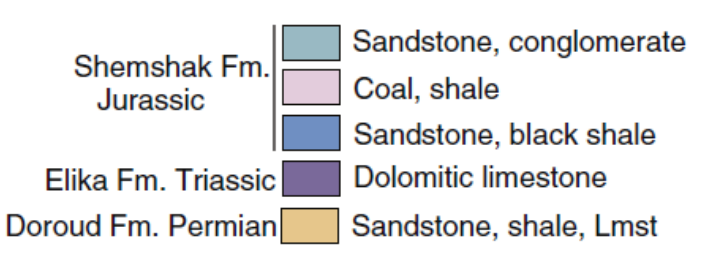




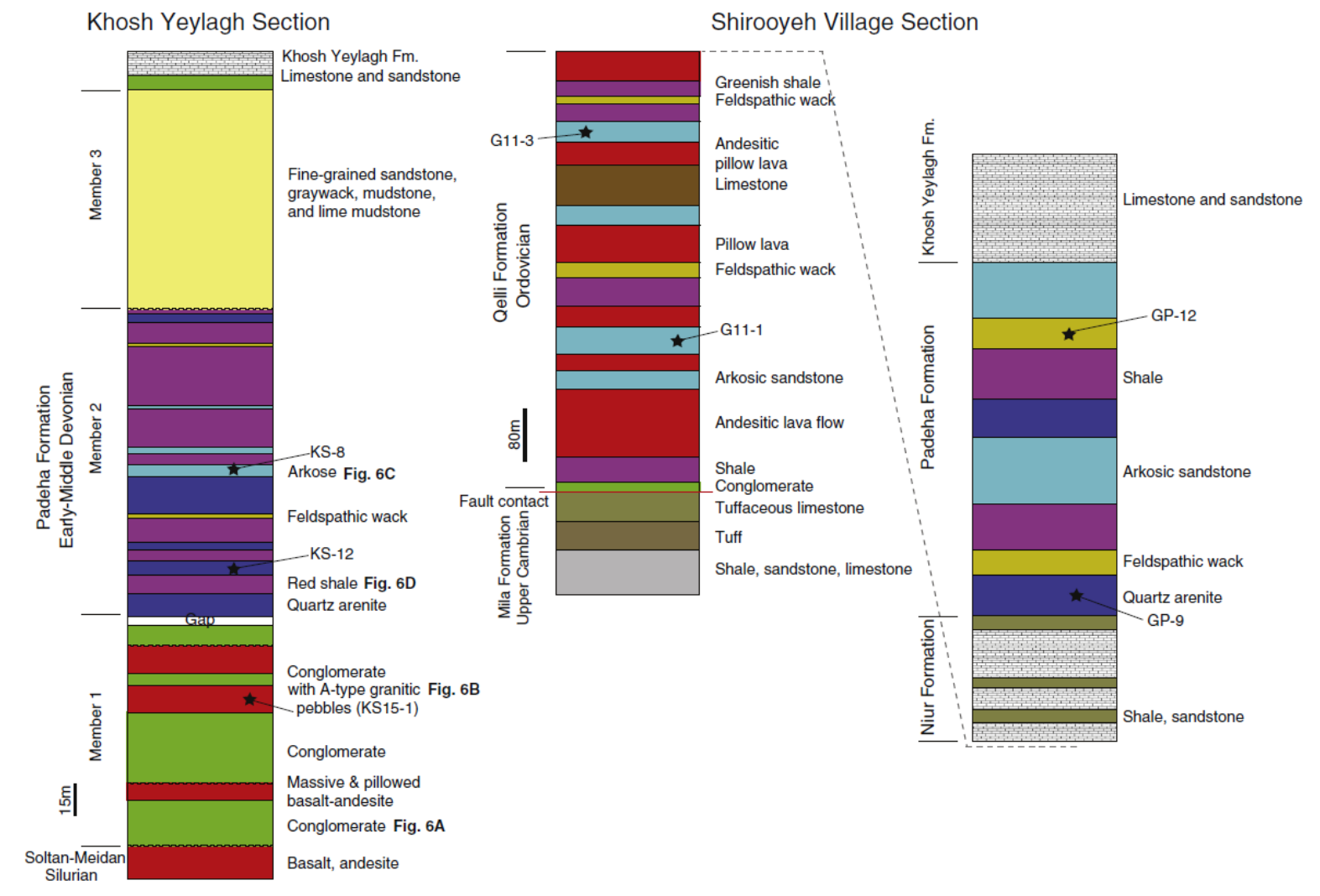

Fig. 5 

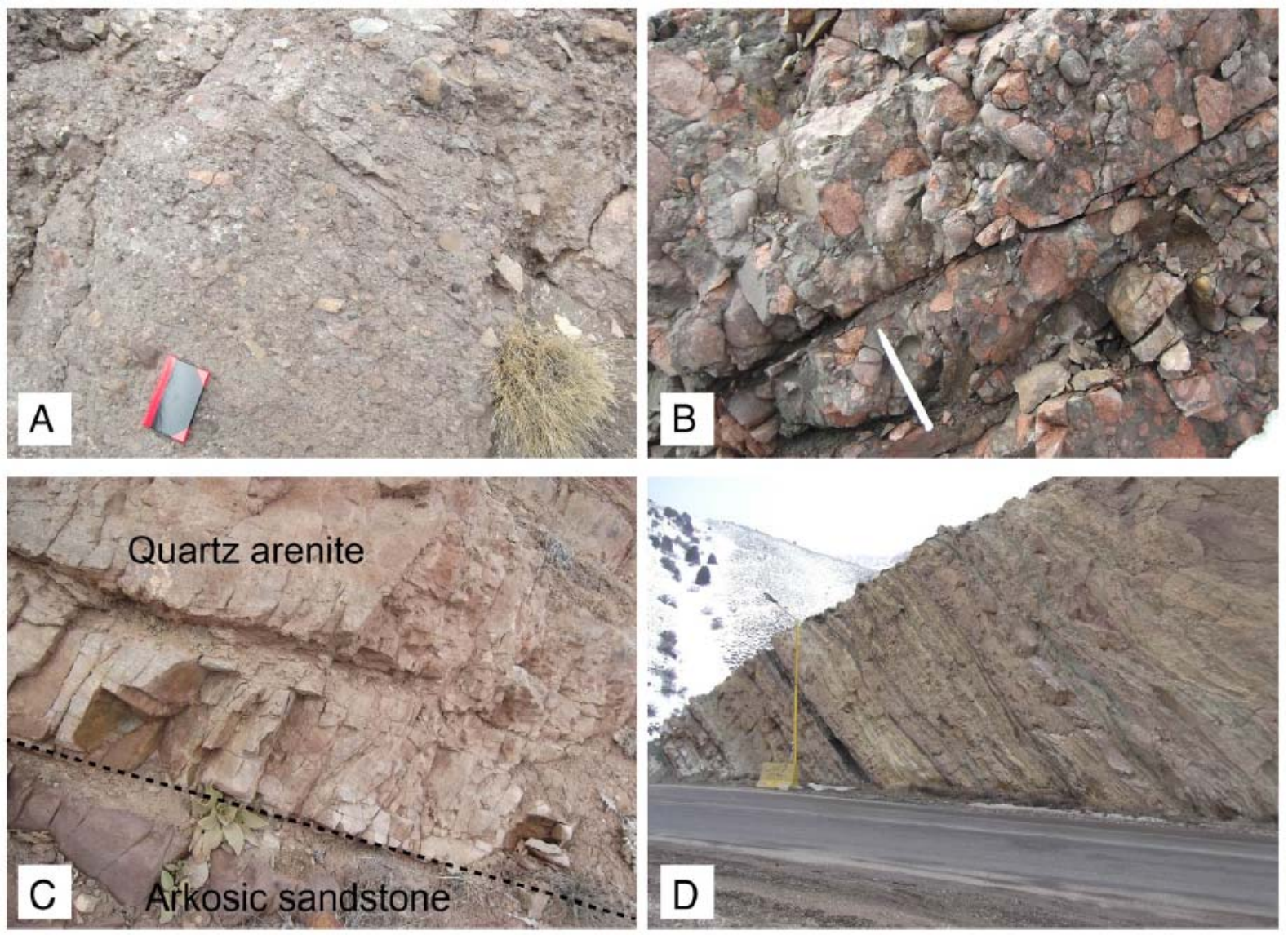

Fig. 6 


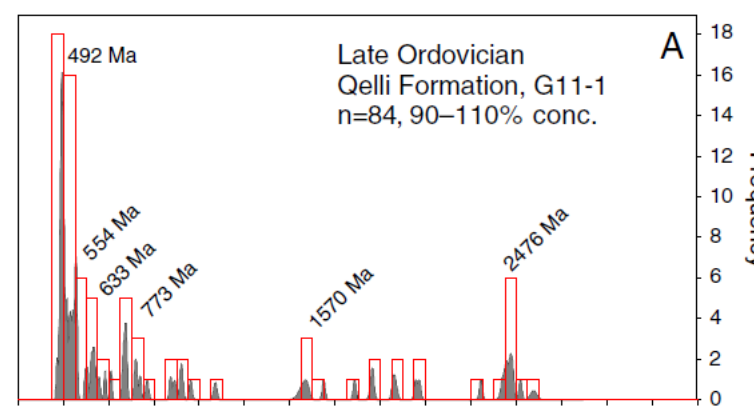

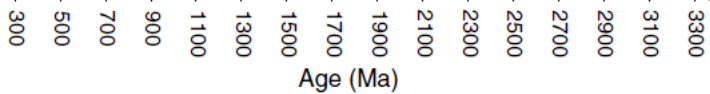

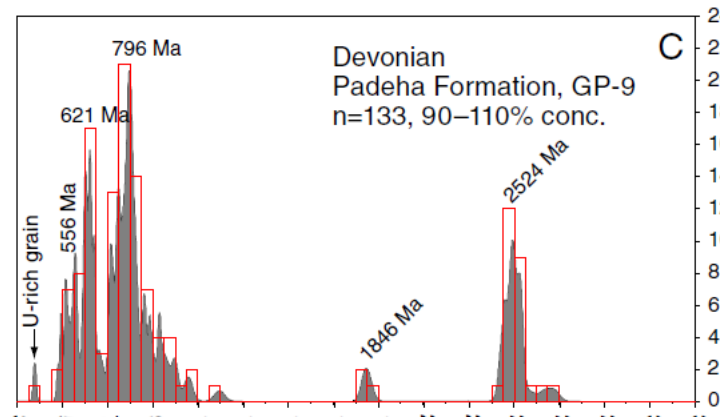

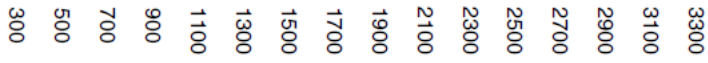
Age (Ma)

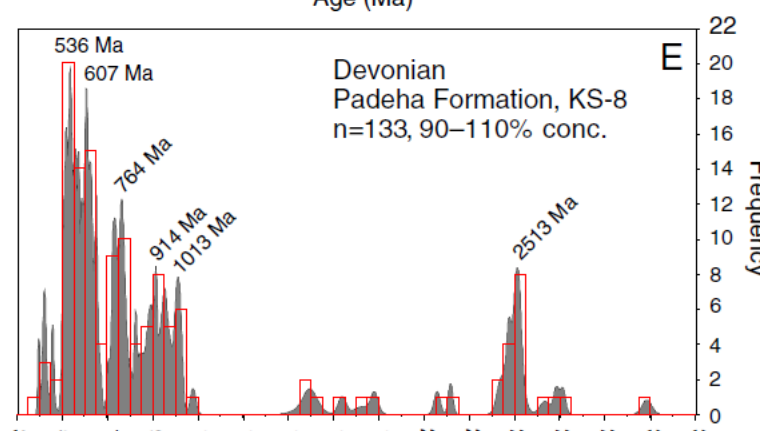

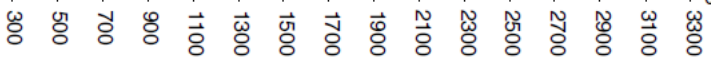
Age (Ma)
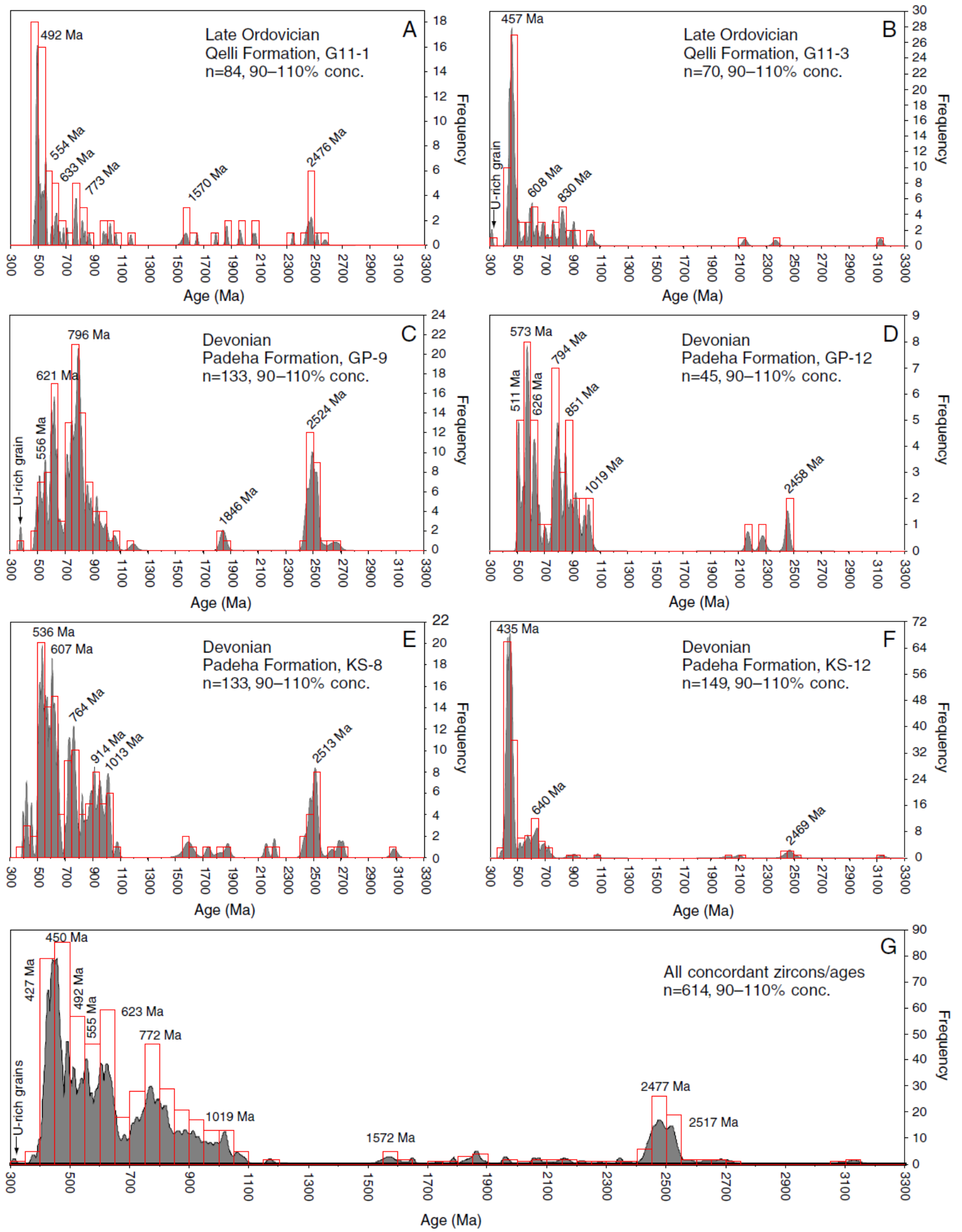

Fig. 7 


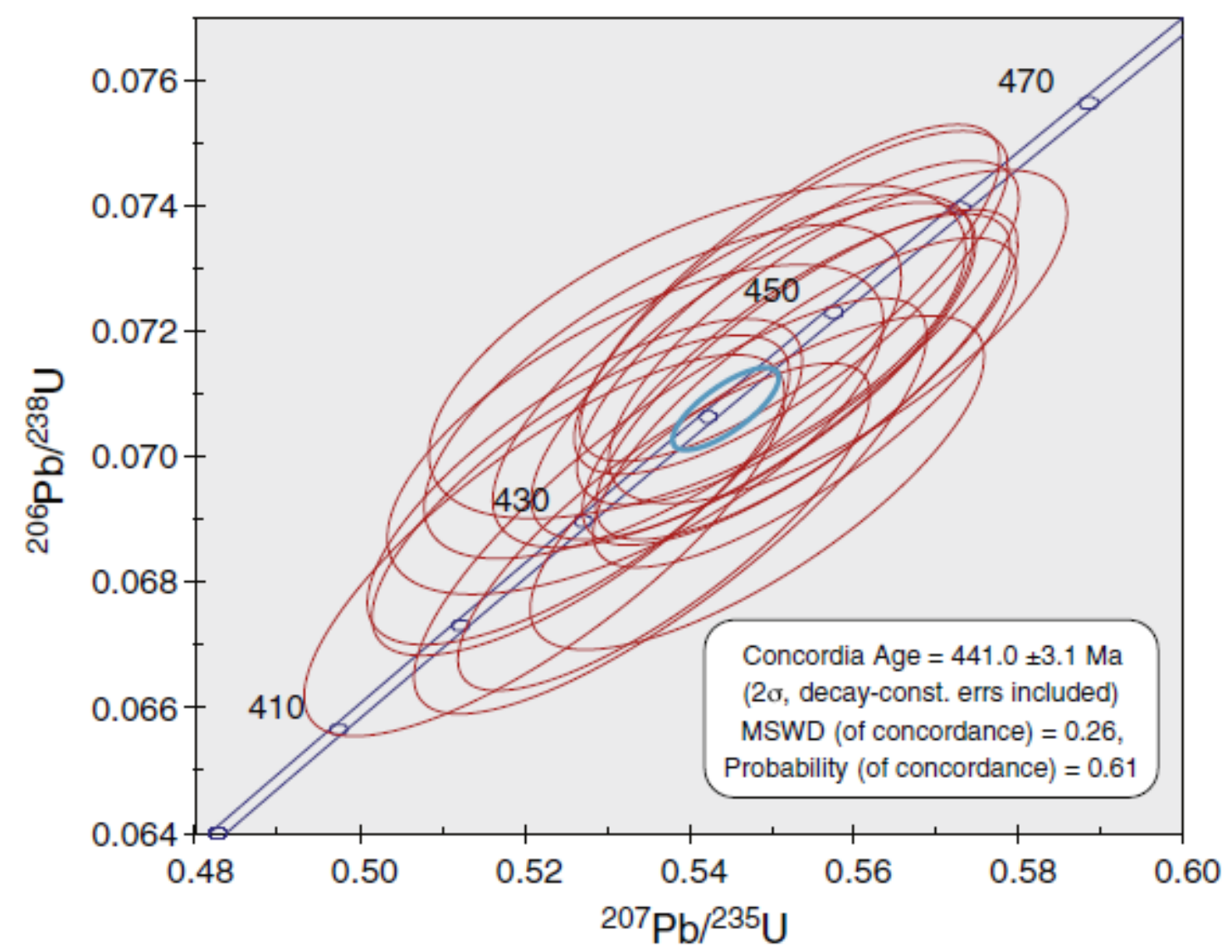

Fig. 8 

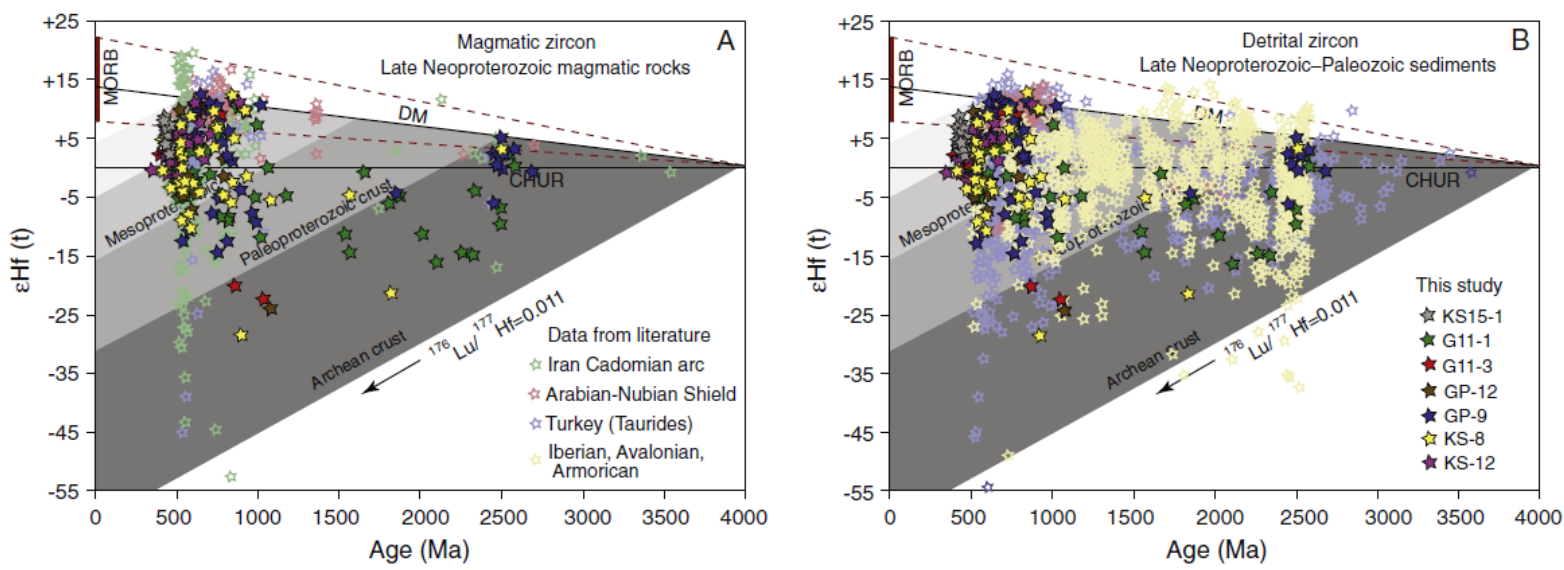

Fig. 9 


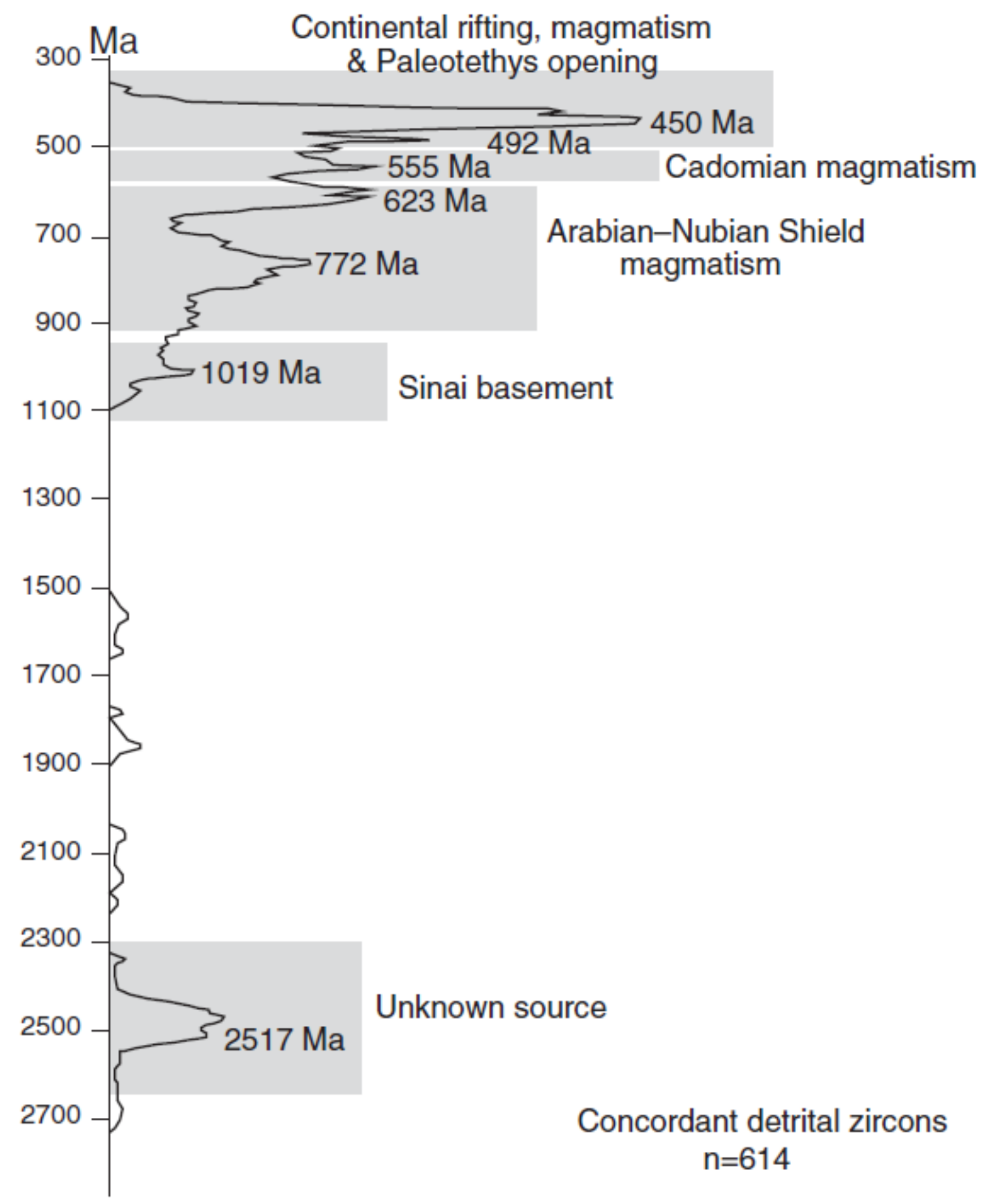

Fig. 10 


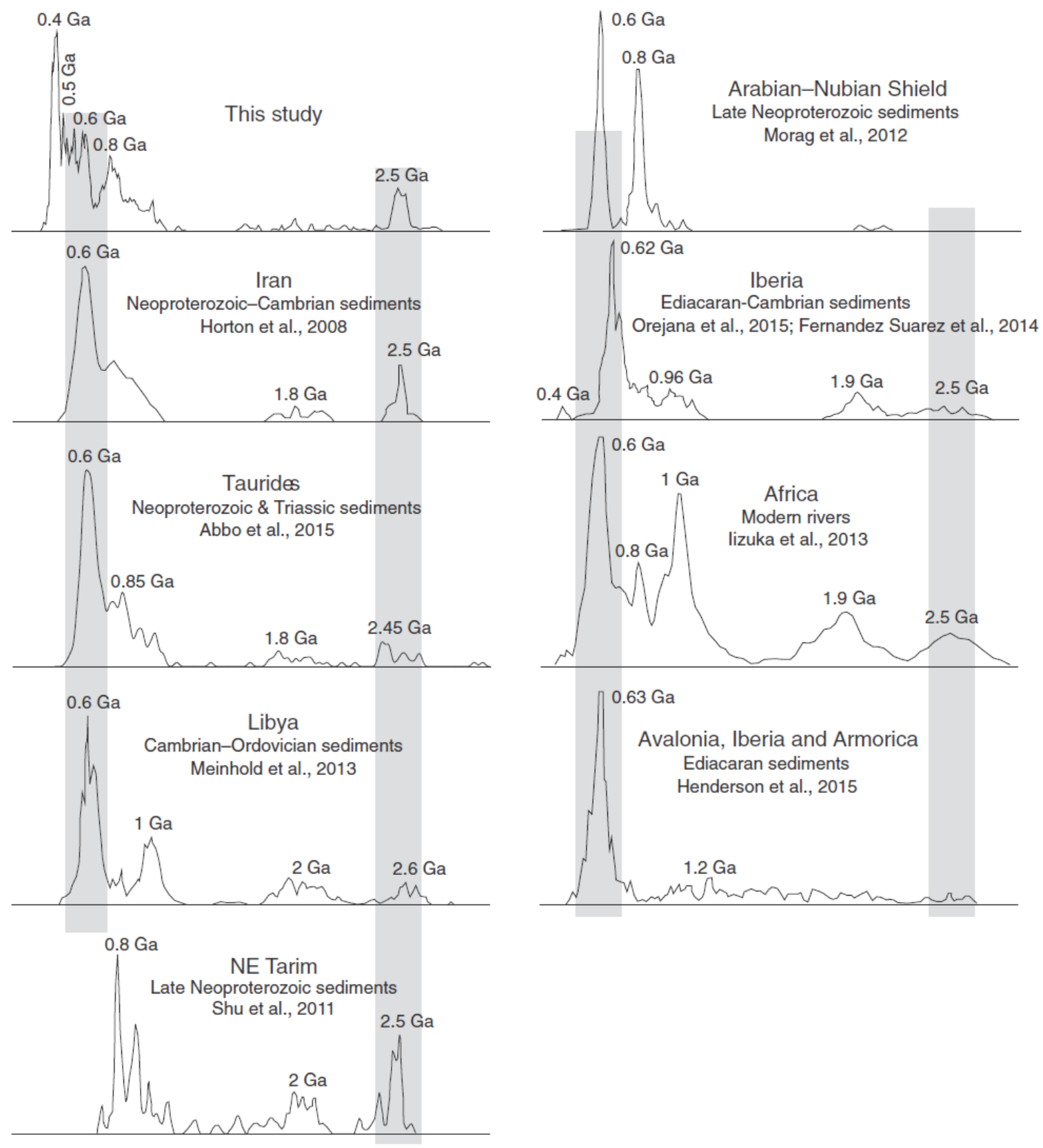

Fig. 11 


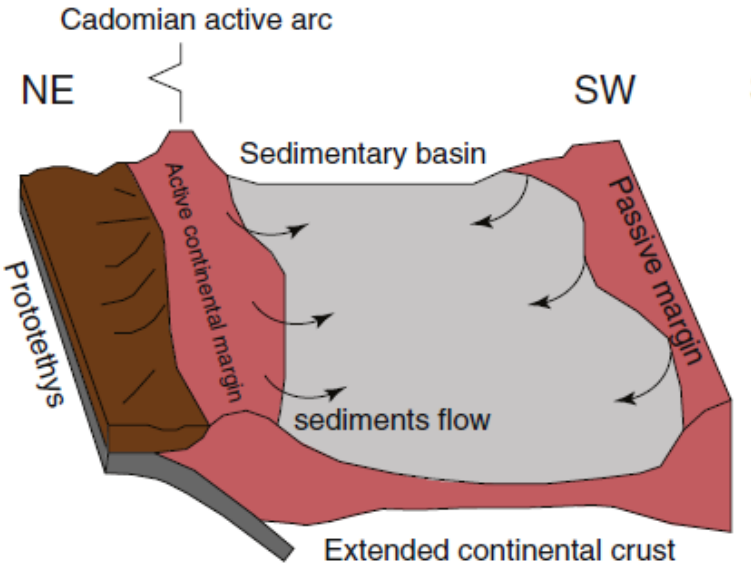

A) Late Neoproterozoic-Early Cambrian
Cadomian

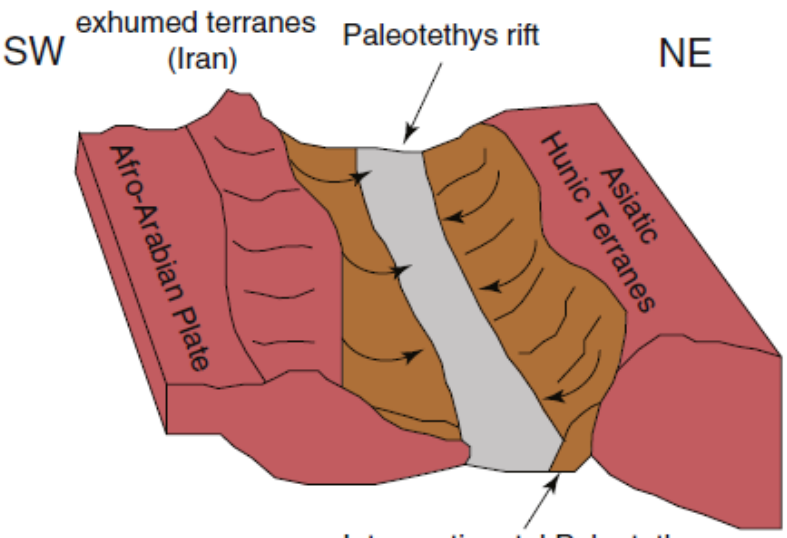

Intracontinental Paleotethys -related magmatism

B) Late Cambrian-Ordovician

Fig. 12 
Table 1

\begin{tabular}{|c|c|c|c|c|c|c|}
\hline Stratigraphic age & Late Ordovician & Late Ordovician & Devonian & Devonian & Devonian & Devonian \\
\hline Formation & Qelli Formation & Qelli Formation & Padeha Formation & Padeha Formation & Padeha Formation & Padeha Formation \\
\hline Sample & G11-1 & G11-3 & KS-8 & KS-12 & GP-9 & GP-12 \\
\hline Number of zircon grains analyzed & 90 & 73 & 156 & 152 & 148 & 54 \\
\hline Number of measurement points & 90 & 76 & 156 & 152 & 148 & 57 \\
\hline Number of concordant ages & 84 & 70 & 133 & 149 & 133 & 45 \\
\hline Number of concordant ages in \% & 93 & 92 & 85 & 98 & 90 & 79 \\
\hline Weighted mean age of youngest coherent population (Ma) & 484.5 & 439.9 & 424.1 & 403.8 & 517.0 & 515.8 \\
\hline Uncertainties (Ma) & $+3.5 / /-6.5$ & $+2.8 / /-10.9$ & $+29.8 / /-6.1$ & $+5.2 / /-10.1$ & $+18.6 / /-5.2$ & $+14.5 / /-7.8$ \\
\hline Confidence (\%) & 96.9 & 97.9 & 87.8 & 93.8 & 93.8 & 87.8 \\
\hline Number of grains of youngest coherent population & 6 & 10 & 4 & 5 & 5 & 4 \\
\hline
\end{tabular}

Note: concordant zircon ages are less than $10 \%$ discordant.Weighted mean age of youngest coherent zircon population was calculated using "TuffZirc Age" in the Isoplot Excel macro of Ludwig (2003a, 2003b).

Uncertainties in ages are quoted at the 2-sigma (95\% confidence) level. 